\title{
Identification of Bacteria by Computer: Identification of Reference Strains
}

\author{
By ShOSHANA BASCOMB,* S. P. LAPAGE, M. A. CURTIS \\ AND W. R. WILLCOX \\ Computer Trials Department, National Collection of Type Cultures, \\ Central Public Health Laboratory, Colindale Avenue, London NW9 $5 \mathrm{HT}$
}

(Received 8 November 1972; revised I9 March 1973)

\begin{abstract}
SUMM A R Y
The results of the identification of 1079 reference strains of Gram-negative, aerobic, rod-shaped bacteria by a probabilistic method in a computer are given. Comparison of identification by conventional methods and by computer showed that $90.8 \%$ of fermentative and $82.1 \%$ of non-fermentative strains could be identified on the best available probability matrix. Many of these strains were atypical and had caused difficulty in identification in the medical diagnostic laboratory. The implications of various factors in successful computer identification are discussed and the results are given for each taxon by genus and species.
\end{abstract}

\section{INTRODUCTION}

Dybowski \& Franklin (1968) gave the first detailed account of bacterial identification by a probabilistic method and were uncertain of its value. Lapage, Bascomb, Willcox \& Curtis (1970) successfully identified 70 to $80 \%$ of 279 freshly isolated strains examined in both a limited number of tests and in all the tests included in their survey. General aspects of probabilistic identification are discussed in Lapage, Bascomb, Willcox \& Curtis (I973) and the mathematical model is described in Willcox, Lapage, Bascomb \& Curtis (I973).

In this paper are presented the results obtained in the identification of 1079 reference strains of bacteria by a probabilistic method used in a computer (Lapage et al. 1970, 1973).

\section{METHODS}

Overall procedure. As a model for trials of computer identification, Gram-negative, aerobic, rod-shaped bacteria which grew on nutrient agar at 37 or $22{ }^{\circ} \mathrm{C}$ were chosen. A matrix was constructed which gave the probability of a strain of any given taxon yielding a positive result in each of the chosen tests (Tables I, 2). Individual strains were then tested and identified on the basis of these results.

Taxa. The taxa chosen for the matrix are given in Tables I and 2. Table I contains those taxa which gave a fermentative result in the oxidation/fermentation test $(\mathrm{O} / \mathrm{F}$ test) of Hugh \& Leifson (I953), while the bacteria in Table 2 gave either an oxidative result, produced no acid in the test, or gave an alkaline reaction. They are referred to as non-fermentative bacteria.

The taxa were selected chiefly on their medical importance and as those likely to occur

* Present address: Department of Biochemistry, Imperial College, Imperial Institute Road, London, $\mathrm{SW}_{7} 2 \mathrm{AZ}$. 
Table 2. Matrix of taxa versus tests for non-fermentative bacteria

Each entry is the estimated percentage probability that a strain of the relevant taxon will give a positive result in the test concerned.

These probabilities (Matrix 68) were, with minor changes, those used during the course of this study. Some of the probabilities differ from the values that would be allotted if the results of tests on strains received after I 968 were included. These should be taken into consideration in a future revision of the matrix. To publish a further revision of the matrix at this stage would be misleading as we have no knowledge of the identification rate which would be achieved with such a matrix. However, some of the values given in Tables I and 2 are not those which we would recommend for diagnostic usage under the specified conditions of testing.

Motility at $37^{\circ} \mathrm{C}$

Motility at RT

Growth at $37^{\circ} \mathrm{C}$

Growth at RT

MacConkey agar, growth

Catalase, presence

Oxidase, presence

Gelatin liquefaction within 5 days

Gelatin liquefaction within 28 days

Hugh \& Leifson test, oxidative

Hugh \& Leifson test, fermentative

Hugh \& Leifson test, alkaline

Simmons' citrate, growth

$\mathrm{KCN}$ medium, growth

Gluconate reduction

Malonate utilization

Deamination of phenylalanine

Urease, presence

Indole production

$\mathrm{H}_{2} \mathrm{~S}$ production (TSI)

$\mathrm{H}_{2} \mathrm{~S}$ production (lead acetate paper)

Arginine, dihydrolase

Lysine, decarboxylase

Ornithine, decarboxylase

Methyl red at $37^{\circ} \mathrm{C}$

Methyl red at RT

Voges-Proskauer at $37^{\circ} \mathrm{C}$

Voges-Proskauer at RT

Nitrate reduction

Selenite reduction

Gas production from glucose

Production of acid from:

Glucose

Adonitol

Arabinose

Cellobiose

Dulcitol

Glycerol

Inositol

Lactose

ONPG*

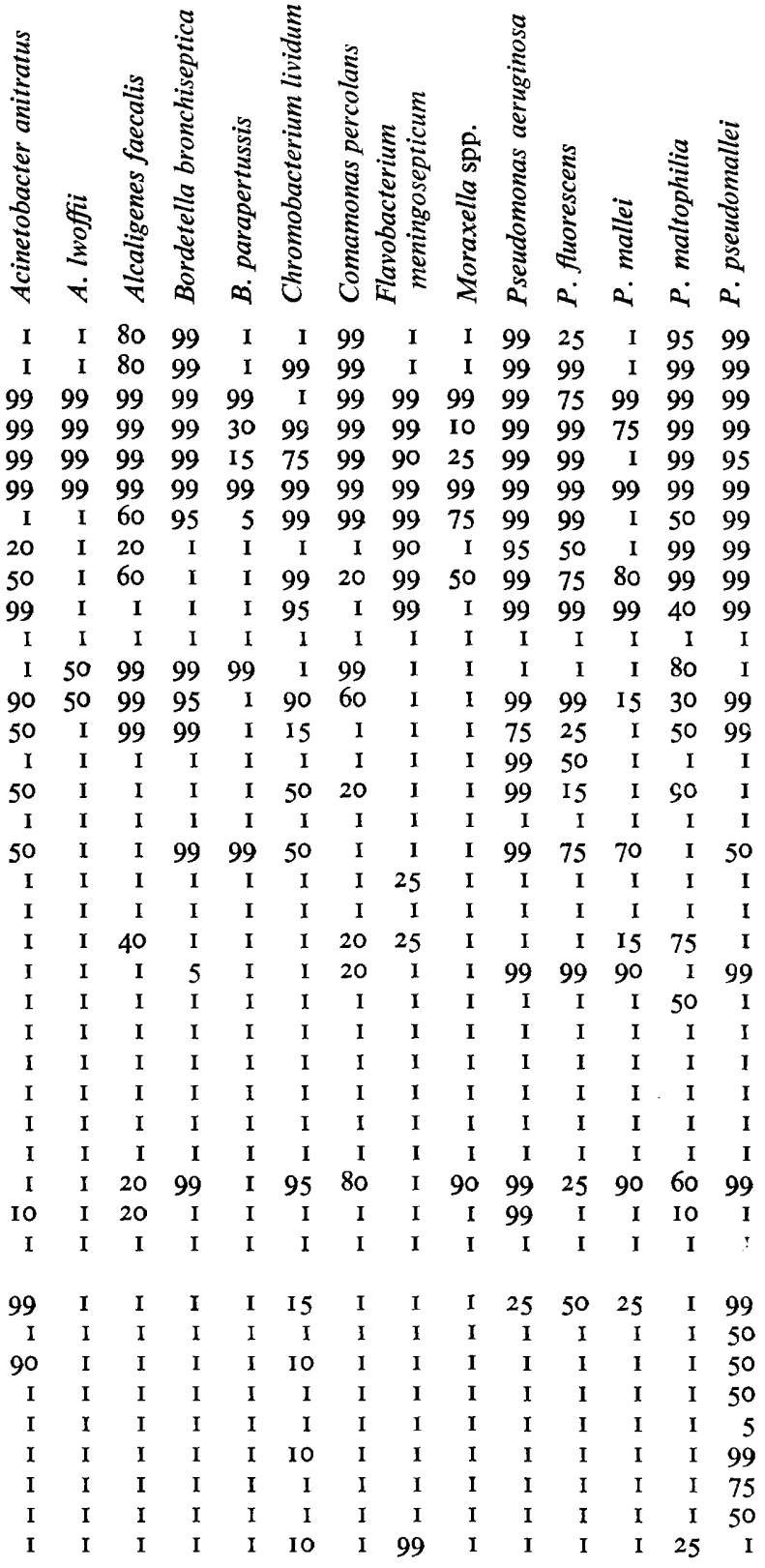


Motility at $37^{\circ} \mathrm{C}$ Growth at $37^{\circ} \mathrm{C}$ MacConkey agar, growth Catalase, presence
Oxidase, presence

elatin liquefaction within 5 days ugh \& Leifson test, oxidative Hugh \& Leifson test, fermenta
Hugh \& Leifson test, alkaline Simmons' citrate, growth KCN medium, growth Malonate utilization Urease, presence Indole production ${ }_{\mathrm{H}_{2}} \mathrm{~S}$ production (TSI) Arginine, dihydrolase
ysine, decarboxylase Ornithine, decarboxyla Methyl red at RT Voges-Proskauer at $37^{\circ} \mathrm{C}$
Voges-Proskauer at RT Nitrate reduction Gas production from glucose Production of acid from: Adonitol

Arabinose

Dulcitol

Inositol

Lactose

Mannitol

Rhamnose

Salicin

Sorbitol

Sucrose
Trehalose

Xylose
Dirty coloured pigment

Brown pigment

Violet pigment

Yellow pigmen
Red pigment

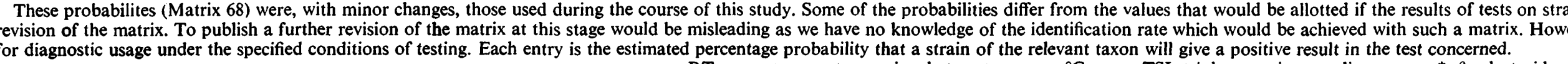
RT, room temperature or incubator at 22 or $30^{\circ} \mathrm{C}$.
TSI, triple sugar iron medium.

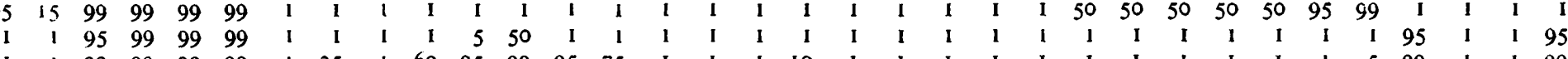

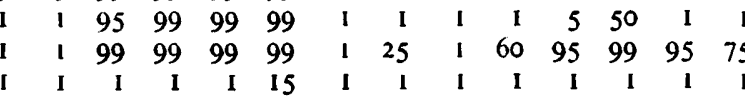

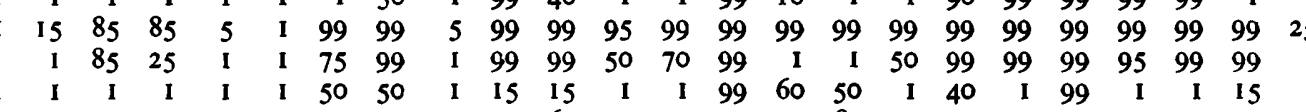

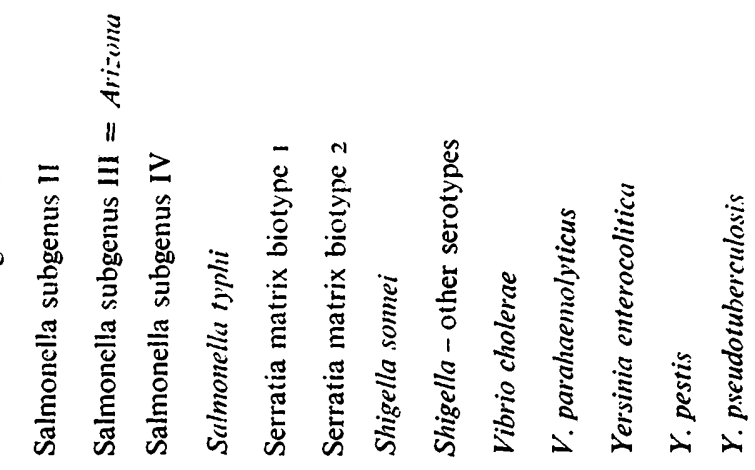

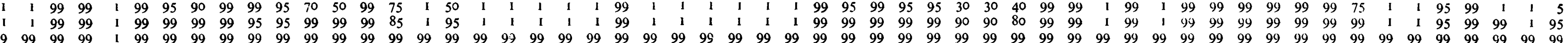

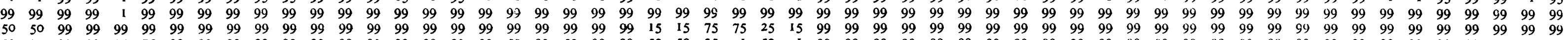

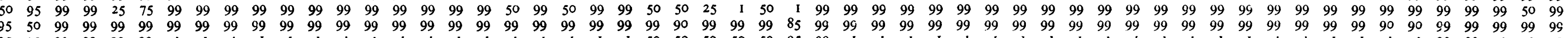

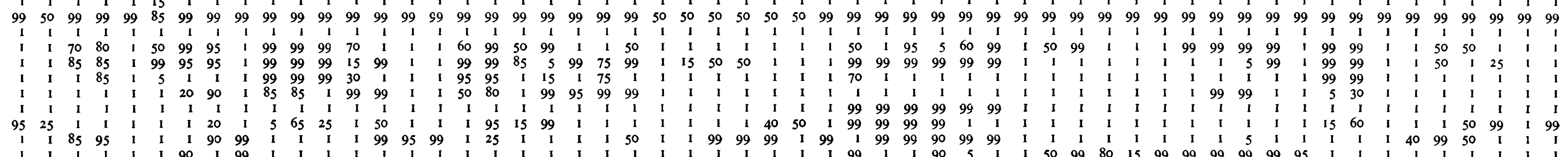

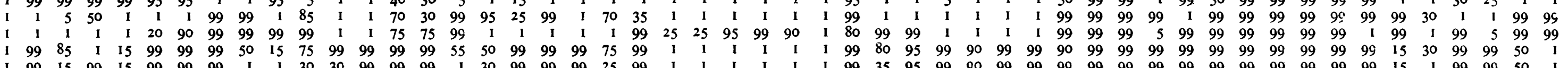
$\begin{array}{llllllllllll}99 & 99 & 99 & 15 & 1 & 99 & 99 & 50 & 1 & 95 & 99 & 99\end{array}$

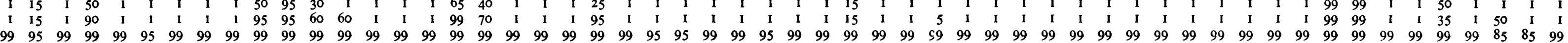

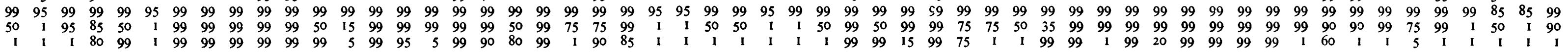

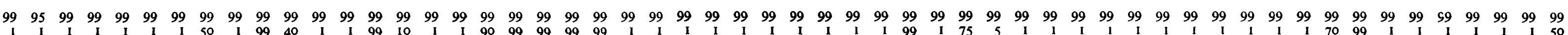

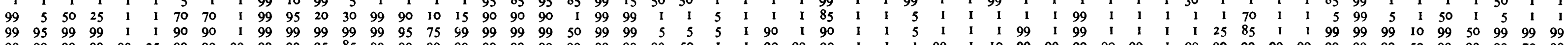

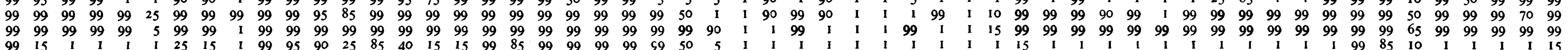

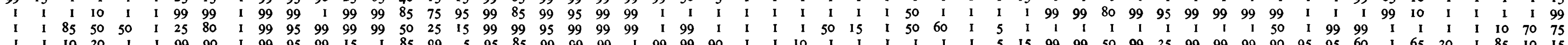

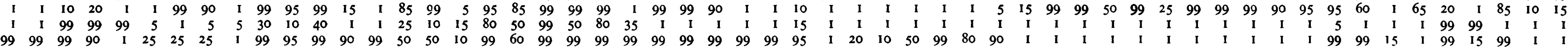

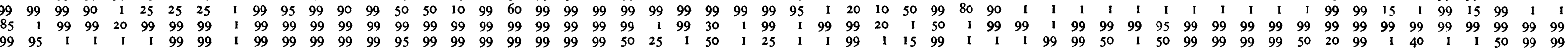




\section{Identification of reference strains}

Table 2. (cont.)

Maltose
Mannitol
Raffinose
Rhamnose
Salicin
Sorbitol
Starch
Sucrose
Trehalose
Xylose
Dirty coloured pigment
Brown pigment
Violet pigment
Green pigment
Yellow pigment
Red pigment

\begin{tabular}{|c|c|c|c|c|c|c|c|c|c|c|c|c|c|}
\hline 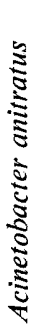 & $\begin{array}{l}\frac{\mathbf{S}}{8} \\
\frac{\mathbf{z}}{\mathbf{i}}\end{array}$ & 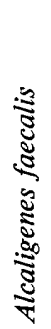 & 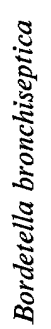 & 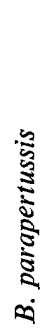 & 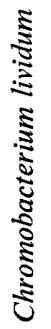 & 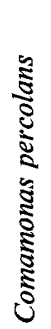 & 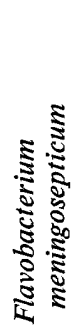 & 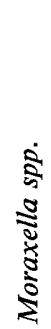 & 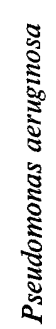 & 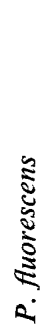 & 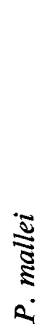 & 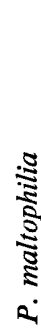 & 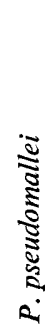 \\
\hline 1 & I & I & I & I & 10 & $I$ & I & I & I & 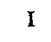 & 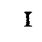 & I & 90 \\
\hline I & I & I & I & I & $\pi$ & I & I & I & & I & I & I & 10 \\
\hline I & I & I & I & I & I & I & I & I & & I & I & I & 10 \\
\hline I & I & I & I & I & I & I & I & I & & 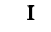 & I & I & I \\
\hline I & I & 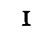 & I & I & I & I & I & I & & I & I & I & 50 \\
\hline 1 & I & I & I & I & I0 & I & 1 & I & & 1 & $\alpha$ & $\mathbf{I}$ & \\
\hline I & I & I & I & I & I & I & I & I & & 1 & 1 & I & 50 \\
\hline I & I & I & I & I & 1 & I & 1 & I & & 1 & 1 & I & 50 \\
\hline I & I & I & I & I & 1 & I & I & I & & I & 1 & I & 75 \\
\hline & I & I & I & I & IO & I & I & I & I & I & I & I & 50 \\
\hline I & I & I & I & I & I & I & I & I & I & I & 1 & I & 20 \\
\hline I & I & I & I & I & 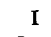 & I & I & I & I & I & I & $\mathbf{I}$ & \\
\hline I & I & I & I & I & 80 & I & I & I & I & I & 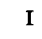 & I & \\
\hline I & I & I & I & I & I & I & I & I & 50 & I & I & I & \\
\hline 1 & I & I & 1 & I & 1 & I & 50 & I & 5 & 25 & I & I & \\
\hline & I & I & I & I & & I & I & I & 5 & I & & $\mathbf{I}$ & \\
\hline
\end{tabular}

* $\beta$-galactosidase. RT, room temperature or incubator at 22 or $30^{\circ} \mathrm{C}$. TSI, triple sugar iron medium.

in medical specimens. The majority are recognized species, genera or subgenera. One had been informally named the 'R.M. bacterium' (Ross, Rucker \& Ewing, I966) and others were taxa specially constructed for use in the matrix but not recognized in classical taxonomy by that name, e.g. Citrobacter matrix biotype 2, Klebsiella unnamed group and Pasteurella multocida matrix biotype 2 .

Tests. Since identification was to be made both on the results from our own and other laboratories (Lapage et al. 1973), the 48 tests chosen (Table I) were those considered easy to read, reproducible, least affected by subjective interpretation and commonly used in the medical diagnostic bacteriological laboratory. In practice, 56 test results were available, 48 tests were set up of which one, pigmentation, if present, provided a choice of six possible colours, gelatin liquefaction provided two results and the $\mathrm{O} / \mathrm{F}$ test three results. These 56 test results were allotted probabilities for each taxon in the matrix (Tables I, 2).

Methods. The media and methods used correspond in general to those described by Cowan \& Steel (1965) and are given in Bascomb, Lapage, Willcox \& Curtis (1971). All tests were read at I, 2 and finally at 5 days, except for gelatin liquefaction which was read up to 28 days.

Coding of tests. Most of the tests were recorded as four-state $(+, \pm, \mp,-)$. Pigment was coded as absent or present, when it was then coded from a choice of six colours (Table I). Acid production from carbohydrates was allowed three states (acid, weak acid or no acid) and gas production from glucose three states (gas, little gas or no gas). The O/F test was coded as three-state; oxidative, fermentative or alkaline. All coded characters were stored in the computer, and before the calculations of the identification scores, ' \pm ', 'weak acid' and 'a little gas' were equated with ' + '; and ' $\mp$ ' was equated with '-' so that the characters 


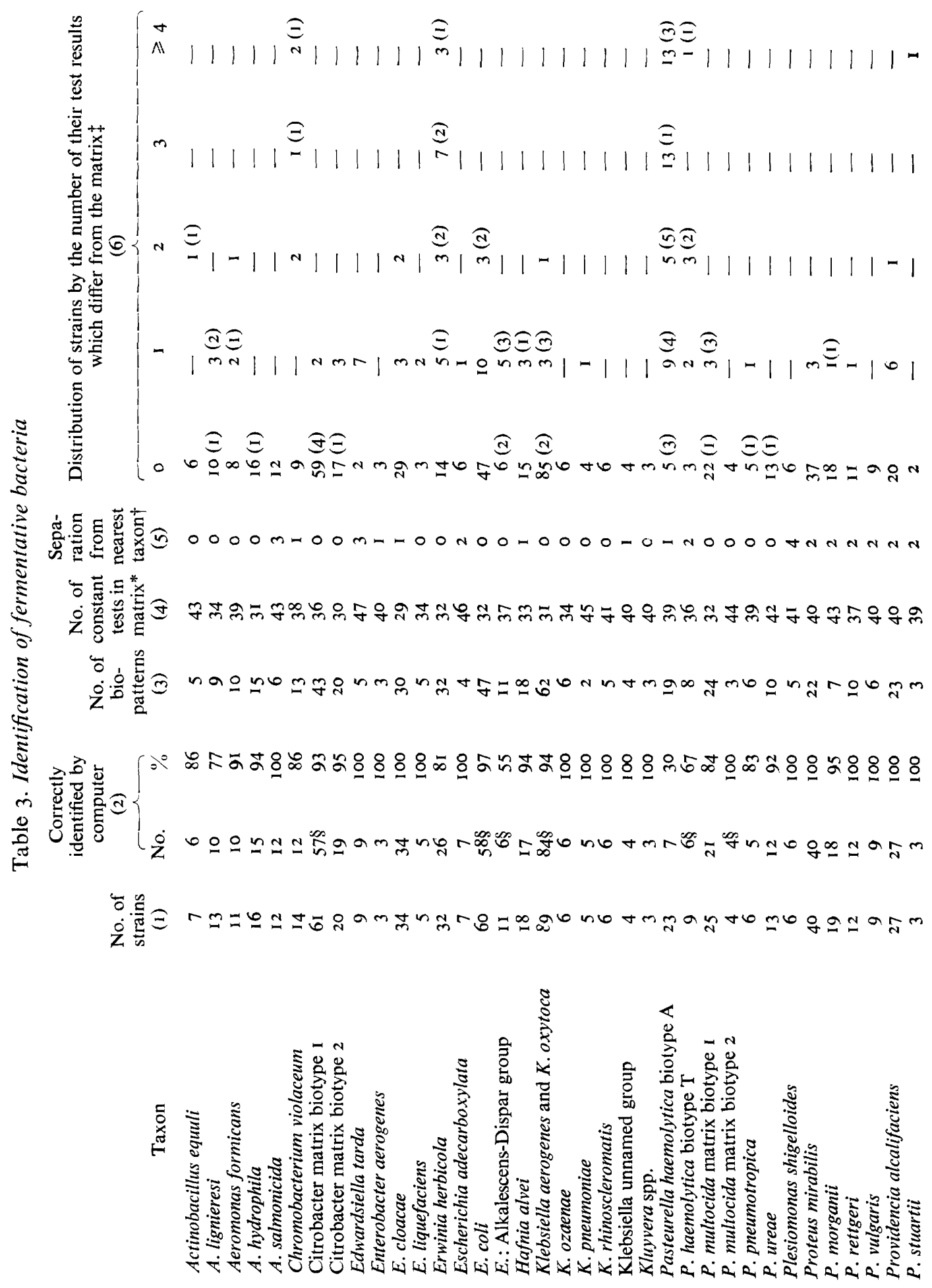




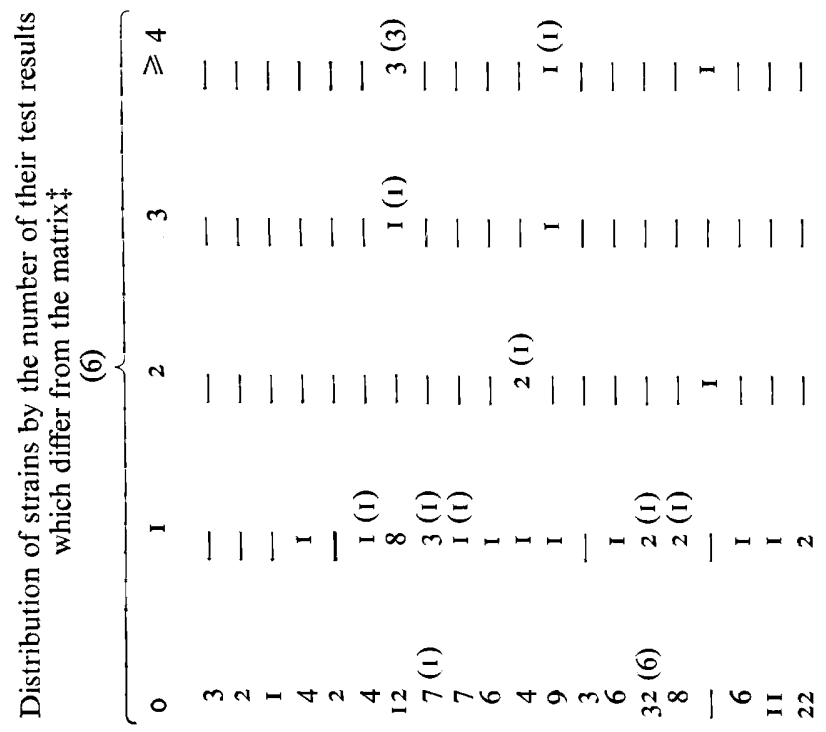

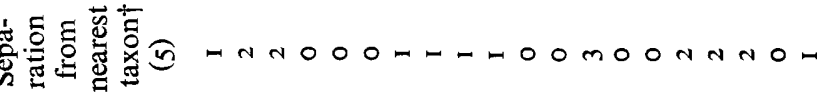

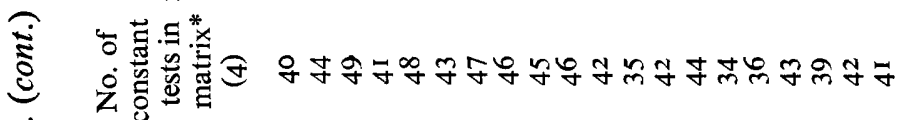

m

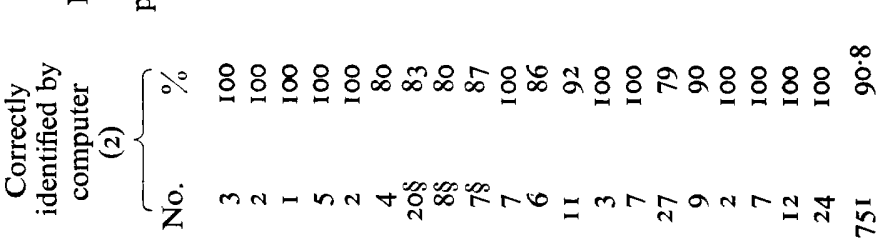

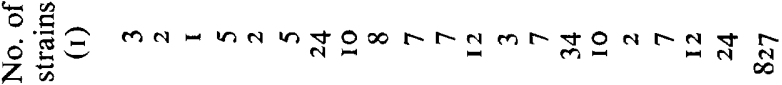

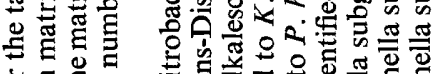

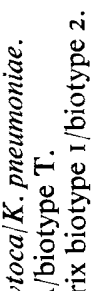

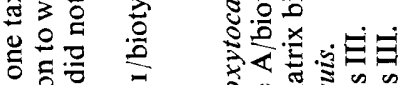

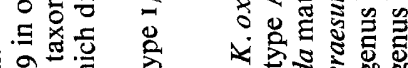

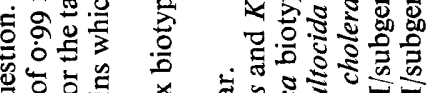

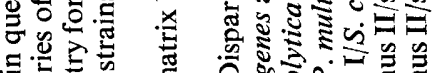
चี 肴.

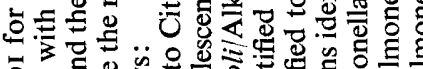

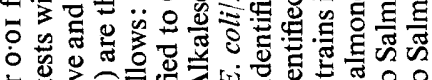

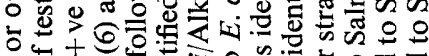

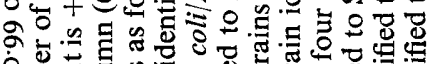

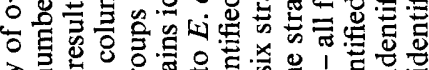

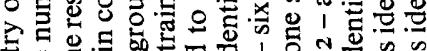
E⿺辶.

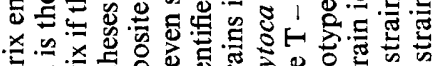

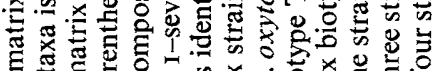<smiles>[CH][CH]</smiles>
ส

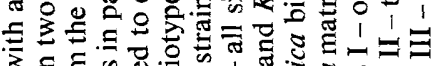

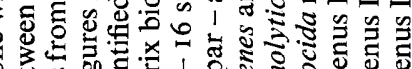

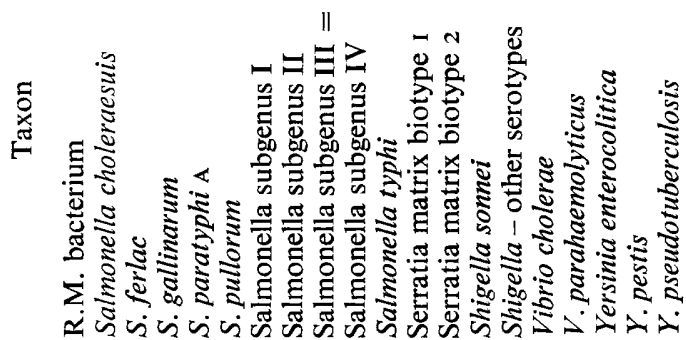

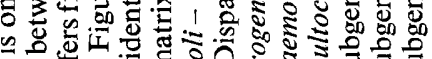

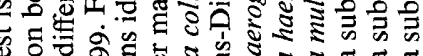

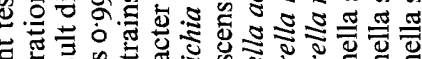

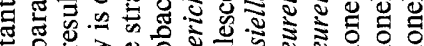
ฐ $\begin{aligned} & 5 \\ & 0\end{aligned}$

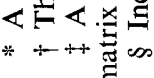


were treated as two-state in the identification calculations, apart from the multistate characters.

Linkage of tests. Test linkage was taken into account in the calculations for certain tests (Willcox et al. 1973). Some tests were carried out at more than one temperature and allowance was made for growth at the different temperatures (motility at room temperature (RT) or $37^{\circ} \mathrm{C}$, methyl red test (MR) at RT and $37^{\circ} \mathrm{C}$, Voges-Proskauer test (VP) at RT and $37^{\circ} \mathrm{C}$ ). Gelatin liquefaction was scored as two tests - early ( $\mathrm{I}$ to 5 days) or overall (I to 28 days) - and these were treated as linked. Failure to produce acid from glucose peptone water was linked with failure to produce gas. $\mathrm{H}_{2} \mathrm{~S}$ production tested both by lead acetate papers and by triple sugar iron agar were treated as linked since most strains showed correlation of the results in these tests although the biochemical pathways involved are dissimilar (Lapage \& Bascomb, 1968).

The $\mathrm{O} / \mathrm{F}$ test results were treated as a multistate test since a fermentative result excludes an oxidative result or failure to produce acid, and the converse also holds; alkali production was treated independently. Pigment production with the six possible colours was also treated as a multistate test (Willcox et al. 1973).

Construction of matrix. The first matrix, Matrix 66 (Lapage et al. 1973), which was completed in 1966 , was drawn from laboratory records and published data, including standard textbooks. By 1968 further information was available, particularly from tests in our laboratory by standardized methods on many strains, and a new matrix, Matrix 68, was prepared and has been in use since. The sources for the data used for each taxon are described under Results. The results given in this paper were all obtained with Matrix 68, which has shown a higher success rate in all cases than Matrix 66 (Lapage et al. 1973). Strains tested before the compilation of Matrix 68 and previously identified with Matrix 66 were re-identified on Matrix 68.

The probability values allotted for each taxon in each test had upper and lower limits of 0.99 and 0.01 with values between, in 0.05 intervals, from 0.95 to 0.05 . The matrix was kept under review as further data became available although automatic adjustments were not made in the computer as each strain was examined (Lapage et al. 1973). Matrix 68 is given in Tables $\mathrm{I}$ and 2 for fermentative and non-fermentative bacteria respectively.

Probabilistic identification. In principle, from the test results given by each strain, an identification score was calculated for each taxon by comparison of the result of each test performed on the unknown strain with the probabilities in the matrix (Willcox et al. 1973). If any score reached a level of 0.999 then the strain was considered to be identified in that taxon. These probabilities (Matrix 68) were, with minor changes, those used during the course of this study. Some of the probabilities differ from the values that would be allotted if the results of tests on strains received after 1968 were included. These should be taken into consideration in a future revision of the matrix. To publish a further revision of the matrix at this stage would be misleading as we have no knowledge of the identification rate which would be achieved with such a matrix. However, some of the values given in Tables I and 2 are not those which we would recommend for diagnostic usage under the specified conditions of testing.

In certain cases if the sum of the identification scores of two particular taxa exceeded 0.999 then the strain was considered to be identified in the combined taxon. The taxa concerned are given in the footnotes to Tables 3 and 4 . Separation of such taxa had proved difficult in construction of the matrix and is perhaps artificial, e.g. Escherichia coli and the Alkalescens-Dispar group.

Strains. The results obtained with 1079 strains collected between I965 and 1970 are 
Identification of reference strains

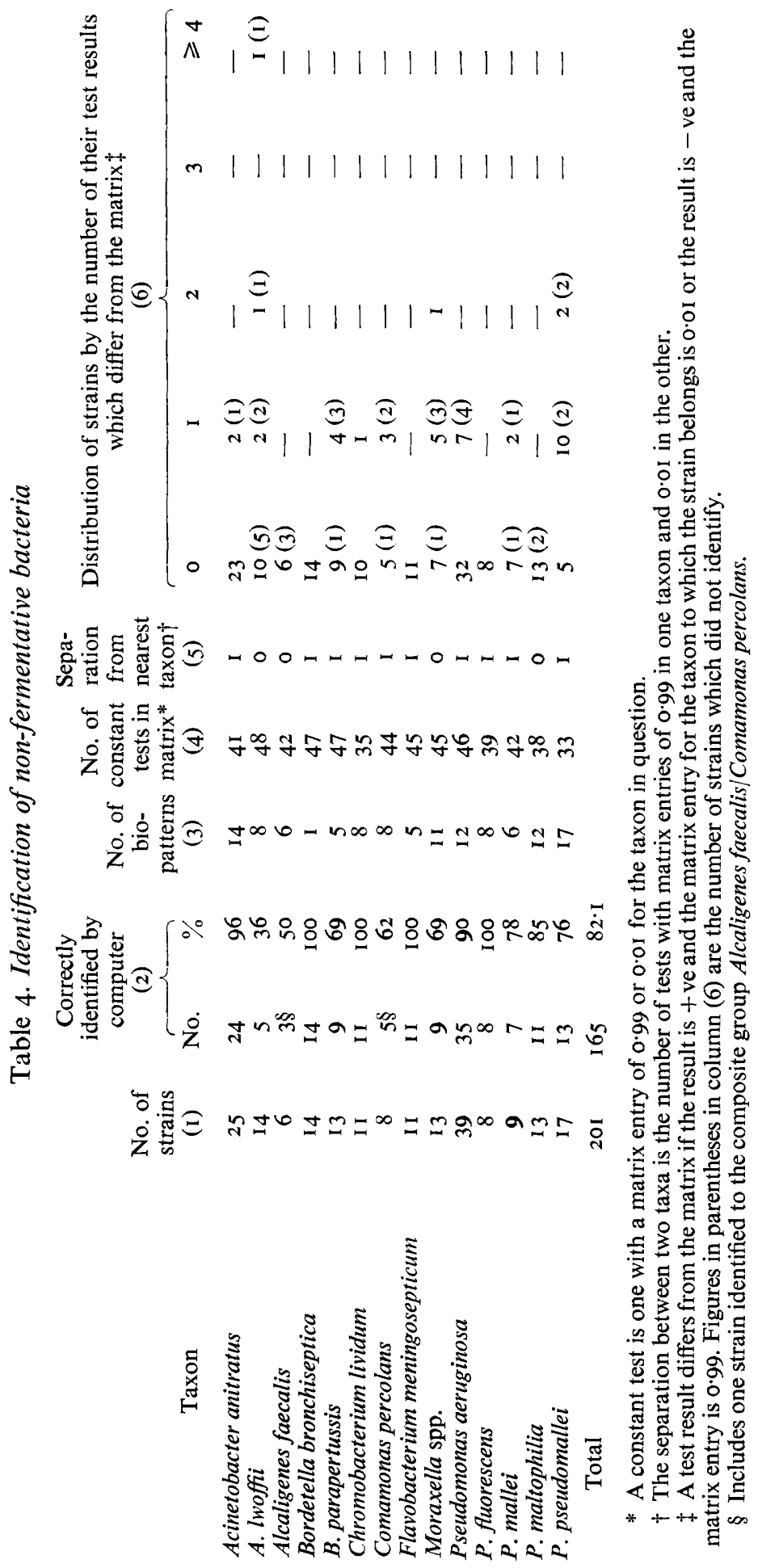


reported. Of these strains, 470 were from culture collections, i.e. NCTC, NCIB, NCMB, NCPPB and ATCC, ${ }^{*}$ and many others were designated strains from experts in the relevant group of bacteria. Also included in these reference strains were some of the strains isolated in our laboratory or sent to us for identification in the early stages of the project. As these were used for reference purposes in our laboratory and were in some cases checked by reference laboratories, they have been included in the reference strains.

Identification procedure. Each reference strain for identification by computer was tested afresh in all the 48 tests, identified conventionally on these results by at least two of us and then identified by the computer method. If the identification differed from the original designation the test results were compared with those available from the source of the reference strain, which often included the results of tests not used in the Computer Laboratory, e.g. morphological tests, antigenic structure or bacteriophage sensitivity. The strains were then assigned to the taxa in the matrix.

Next, the strains were identified by the computer method. The computer decision was compared with the original designation of the strain and with the conventional identification. If the computer identification was the same as the conventional then the computer identification was considered to be correct. Very rarely a strain could not be identified conventionally but the computer suggested an identification. In this case, the results given by the strain were considered, sometimes the strain was retested and if possible additional tests were carried out, e.g. serological. If the evidence was considered sufficient by conventional criteria, the strain was included in the taxon and a correct identification by the computer recorded. If there was any doubt the strain has been excluded from this series.

Successful identification by both conventional and computer methods but into different taxa occurred only once, and this rather trivial case is described under 'Salmonella' in the Results. A failure was scored when a strain was identified by conventional means but not by the computer.

As the purpose of the present investigation was to study computer identification of reference strains, any strain which could not be identified by either conventional or computer methods has been excluded from the following account. A reference strain can of course be an intermediate or highly unusual strain but comparison of two failures in identification was not relevant. Intermediate strains, strains which fail to identify and field strains are discussed in Lapage et al. (1970, I973).

Of the 1079 reference strains which could be identified conventionally, 1028 belonged to taxa included in the matrix, while $5 \mathrm{I}$ were strains of taxa not included in the matrix and were tested to see if they identified in any taxon in the matrix. They were chosen from taxa, Agrobacterium, Rhizobium and Xanthomonas, which might occur in human specimens via plants; from taxa related to those in the matrix, Pseudomonas spp., Vibrio spp. other than $V$. cholerae, and Zoogloea; and from taxa likely to cause confusion, Neisseria.

\section{RESULTS}

Identification of strains of taxa in the matrix. The success of computer identification of the various taxa is given in Tables 3 and 4 for fermentative and non-fermentative bacteria respectively.

The first column gives the number of strains examined, the second the number of strains,

* NCTC, National Collection of Type Cultures; NCIB, National Collection of Industrial Bacteria; NCMB, National Collection of Marine Bacteria; NCPPB, National Collection of Plant Pathogenic Bacteria; ATCC, American Type Culture Collection. 
followed by the percentage, which were correctly identified by the computer method. The totals show that $90.8 \%$ of the strains of fermentative bacteria and $82 . \mathrm{I} \%$ of non-fermentative bacteria were correctly identified. In the case of $30(54 \%)$ of the 56 fermentative taxa, all the strains in the taxon concerned were identified and $90 \%$ or over of the strains were correctly identified in a further I I $(20 \%)$ taxa. In only four $(29 \%)$ of the I4 non-fermentative taxa were all the strains identified and in only two ( $14 \%$ were $90 \%$ or over identified.

Column 3 of Tables 3 and 4 gives the number of strains of each taxon which gave a different pattern of results in the 57 tests carried out, i.e. the number of biopatterns, and, column 4 , the number of matrix entries of 0.99 or 0.01 for each taxon. These two indices express some measure of the homogeneity of the taxon concerned, although in some taxa the number of strains tested are too few to draw any conclusions about the number of biopatterns compared to the number of strains. However, the results obtained with taxa which contained more than 20 strains were analysed and no obvious correlation was found between the identification rate and either the number of biopatterns or the number of matrix entries of 0.99 and 0.01 .

The number of test differences of 0.99 and 0.01 of each taxon from its nearest neighbour (column 5 of Tables 3 and 4) represents the minimum number of such tests available for its differentiation. If the taxa are taken individually the number of $0.99 / 0.01$ separating tests is not a complete guide as to how well strains of the taxon will identify since some taxa with no $0.99 / 0.01$ separating tests gave $100 \%$ identification rates, whereas some taxa with two $0.99 / 0.0$ I separating tests did not. However, at least two 0.99/0.0 I separating tests are required for all taxa before a good identification rate can be assumed. The difference in identification rate for strains of taxa with less than two and strains of taxa with two or more separating tests is significant by the Chi-squared test $(P<0.005)$.

The distribution of the I I 2 strains which failed to identify among those showing nil, one, two, three or four or more differences from matrix entries of 0.99 or 0.01 is shown in column 6 of Tables 3 and 4 . The percentage of these strains which did not identify was in these five categories respectively $4.6 \%$ (no difference), $30 \%$ (one difference), $55 \%$ (two differences), $45 \%$ (three differences) and $69 \%$ (four or more differences). Clearly, as would be expected, the number of differences from definitive matrix entries does play a considerable part.

\section{Separate taxa}

References are given for each taxon to many of the reports consulted during the initial compilation of the matrix and its modifications. However, not every reference consulted can be given because in the early stages of the compilation a wide variety of sources was used and some data obtained by personal communication and adequate records were not kept of all the sources. As well as the references quoted the standard textbooks were consulted in most cases (in particular Breed, Murray \& Smith, I957; Prévot, I96I ; Edwards \& Ewing, I962; Wilson \& Miles, I964; Cowan \& Steel, I965; Kauffmann, I966).

Acinetobacter. (Brooke, I95 I $a$; Brisou \& Prévot, 1954; Klinge, I959; Courtieu, Chassignol \& Longeray, 1961; Cetin, 1962; Hendrie, Hodgkiss \& Shewan, I964; Steel \& Cowan, I964; Gilardi, I967; Thornley, I967; Pintér \& Bende, I968.) Two species were included Acinetobacter anitratus and A. lwoffi. Strains of the species of Achromobacter described by Mannheim \& Stenzel (1962) were included in A. anitratus or A. lwoffii. Of the 25 strains of A. anitratus, $24(96 \%)$ were correctly identified. Acinetobacter anitratus had the highest identification score for the remaining strain but the score for Pseudomonas mallei prevented identification at the level of 0.999 . Only five $(36 \%)$ of the 14 strains of $A$. lwoffi $i$ were cor- 
rectly identified and although the highest scoring taxon in each case was $A$. lwoffii, identification was prevented by the scores for Pseudomonas mallei and Bordetella parapertussis.

Actinobacillus. (Tunnicliff, I94I; Taylor, 1944; Ristic, Herzberg, Sanders \& Williams, 1956; Phillips, I960, I96r ; Vallée, Thibault \& Second, 1963.) Two species were included Actinobacillus equuli and A. lignieresi. Of the 13 strains of $A$. lignieresi, 10 (77\%) identified correctly. With the other three strains, although $A$. lignieresi was the highest scoring taxon, identification was prevented by the scores for $A$. equuli. Of the seven strains of $A$. equuli, six $(86 \%)$ were identified correctly.

Aeromonas. (Griffin, Snieszko \& Friddle, I953; Crawford, I954; Pivnick \& Sabina, I957; Eddy, 1960, I962; Schubert, I960, I961, 1962, 1963, 1964, I967; Ewing, Hugh \& Johnson, I96I; Park, I962; Eddy \& Carpenter, I964; Catsaras \& Buttiaux, I965; Bain \& Shewan, 1968.) Three species were included - Aeromonas hydrophila, A. formicans and A. salmonicida (A. shigelloides is considered under Plesiomonas shigelloides). Of the $\mathrm{I} 6$ strains of $A$. hydrophila, $15(94 \%)$ were correctly identified and of the I I strains of $A$. formicans ten $(9 \mathrm{I} \%)$ were also correctly identified. One strain of each species failed to identify due to the score reached for the other and these were probably intermediate strains. All the 12 strains of A. salmonicida, a very homogeneous species, were correctly identified.

Alcaligenes and Comamonas. (Nyberg, I935; Conn, 1942; Ulrich \& Needham, I953; Galarneault \& Leifson, I956; Moore \& Pickett, I960; Hugh \& Ryschenkow, 1961; Davis \& Park, 1962; Park, 1962; Koontz \& Faber, 1963; Richter \& Kress, 1967.) Two species were included - Alcaligenes faecalis and Comamonas percolans. Both in the compilation of the data on these taxa and in the identification in the matrix it was difficult to differentiate these two species, particularly as the matrix did not include investigation of the arrangement of the flagella.

In Matrix 66, Alcaligenes faecalis and Comamonas percolans were placed in two separate taxa. They were later combined but the combined taxon prevented identification of strains of other taxa. It was therefore decided to keep them separate but allow identification in a combined taxon if the sum of the scores of the two taxa exceeded the identification level of 0.999. The only test in our matrix which provided an 0.99/0.0I separation between the two taxa was growth in KCN medium. Only two $(33 \%)$ of the six strains of $A$. faecalis identified correctly, and of the remaining four only one ( $17 \%$ ) identified in a combined $A$. faecalis/C. percolans taxon. Identification of the other three strains was prevented by the scores for Pseudomonas maltophilia and Bordetella bronchiseptica. Of the eight strains of $C$. percolans, four ( $50 \%)$ were identified correctly and one identified in the combined group taxon. With the three remaining strains identification was prevented by the scores for $P$. maltophilia and $B$. bronchiseptica.

This group of motile organisms, which give few positive results in the usual diagnostic tests, are not easy to differentiate, and included in Alcaligenes faecalis were strains of $A$. faecalis, $A$. faecalis var. odorans, $A$. viscosus and other strains. In Comamonas percolans were included strains of $C$. percolans, Vibrio alcaligenes, Pseudomonas alcaligenes, $P$. pseudoalcaligenes, and other strains. This was done for convenience since the species in each group could not be differentiated on the tests in our matrix. The taxonomic relationships of these organisms appear uncertain and further study is needed.

Bordetella. (Lautrop, I960.) Two species were included - Bordetella bronchiseptica and B. parapertussis. Bordetella pertussis was not included because strains do not in general grow on nutrient agar. All of the I4 strains of $B$. bronchiseptica were correctly identified and appear to form a coherent group. Of the 13 strains of B. parapertussis, nine (69\%) were 
correctly identified but with four strains identification was prevented by the scores for Acinetobacter lwoffii.

Chromobacterium. (Sneath, I956; Moffett \& Colwell, 1968.) The psychrophilic and mesophilic violet-pigmented species Chromobacterium lividum and $C$. violaceum were included. Eleven strains of $C$. lividum were identified correctly, one of these strains was originally designated $C$. amethystinum. Of the I4 strains of $C$. violaceum, I $2(86 \%)$ were correctly identified. The other two showed three and four differences from the matrix entries of 0.99 and $0.0 \mathrm{I}$ and failed to identify although $C$. violaceum was the taxon with the highest identification score.

Citrobacter. (Werkman \& Gillen, 1932; Stuart, Wheeler, Rustigian \& Zimmerman, I943; Davis \& Ewing, 1966.) The genus was divided in our matrix into two taxa-matrix biotype I and matrix biotype 2. Matrix biotype I is equivalent to typical strains of Citrobacter freundii. In Matrix 66 only one species, C. freundii, was included and strains classed as irregular enterobacteria were identified by the computer as Citrobacter freundii although they differed in some tests. These strains were considered to resemble Citrobacter more than any other group and included in the matrix as Citrobacter matrix biotype 2 . They have been independently observed and described by Macierewicz (I966), who named them Padlewskia, by Frederiksen (1970), who named them C. koseri, and by Young, Kenton, Hobbs \& Moody (197I), who named them Levinea. Of the 6I strains belonging to Citrobacter matrix biotype I, $50(82 \%)$ identified correctly and a further seven (I $\%$ ) identified when the combined score for Citrobacter matrix biotype I and matrix biotype 2 was used. Of the 20 strains of Citrobacter matrix biotype 2, $19(95 \%)$ identified correctly. One strain of $C$. ballerupensis whose reactions resembled those of a strain of Salmonella failed to identify although Citrobacter matrix biotype I was the highest identification score with Salmonella subgenus I as the next.

Comamonas. See Alcaligenes and Comamonas above.

Edwardsiella. (Ewing, McWhorter, Escobar \& Lubin, 1965; Ewing, McWhorter, Ball \& Bartes, 1967; Sakazaki, 1967; Bhat, Myers \& Carpenter, 1967.) One species, Edwardsiella tarda, was included and all nine strains were correctly identified.

Enterobacter. (Brooke, 195I b, I953; Report, 1958; Grimes, 196I ; Report, I963; Fife, Ewing \& Davis, 1965.) Three species were included: Enterobacter aerogenes, E. cloacae and E. liquefaciens. The classification of Enterobacter and Klebsiella and the choice of characteristics and taxa for use in the matrix proved difficult and a numerical taxonomy was undertaken (Bascomb et al. I97I). The results of this study were used to improve the matrix and all 3 strains of $E$. aerogenes, 34 of $E$. cloacae and five of E. liquefaciens were correctly identified.

Erwinia. (Cruickshank, I935; Jøker, Nørholm \& Siboni, 1965; Muraschi, Friend \& Bolles, I965; Graham \& Hodgkiss, 1967.) In Matrix 66 two taxa were included: Chromobacterium typhiflavum and Enterobacter 'pigmenté' (Leclerc, 1962). However, the reactions given by the strains of these taxa were found to be similar and the two taxa were combined under the name Erwinia herbicola, of which Graham \& Hodgkiss (1967) had shown $C$. typhiflavum to be a junior synonym. A separate study was made of this group and additional strains included to make a total of 32: C. typhiflavum (5), Enterobacter 'pigmenté' (Io), Erwinia herbicola (10), E. lathyri (2), E. ananas (2), E. milletiae (1) and E. uredovora (2). Many of these 32 strains were from plant sources but $26(8 \mathrm{I} \%)$ were identified, as $E$. herbicola, despite differences in their results of three, four and five from the matrix entries of 0.99 or 0.0 . . Of the six strains which failed to identify, in one case Citrobacter biotype 2 reached the highest identification score and in another Enterobacter cloacae. Possibly 
these strains belonged to these two species. Yellow pigmented strains of Citrobacter have been described by Thomas \& Elson (I957) and several yellow pigmented strains of E. cloacae are kept in the NCTC.

Escherichia adecarboxylata. (Leclerc, 1962.) All the seven strains of this homogeneous species identified correctly. Some strains were non-pigmented and others continuously produced non-pigmented mutants. The exact generic position of this species is not certain.

Escherichia coli and the Alkalescens-Dispar group. Two taxa were included in the matrix: Escherichia coli and the Alkalescens-Dispar group, which may be regarded as part of the species $E$. coli. Strains which were either non-motile, anaerogenic or ONPG and lactosenegative usually did not reach identification level in either group but required a combined score for E. coli and the Alkalescens-Dispar group. Combination of these two groups in the matrix as one taxon, however, led to difficulty in their identification because the scores for Shigella became too high to permit identification. The two groups were therefore kept separate in Matrix 68 but identification was considered correct if the combined score for the two reached the required level of 0.999 . Of the 60 strains of $E$. coli, $42(70 \%)$ identified as $E$. coli while I6 (27\%) identified when the identification score for the combined $E$. coli/ Alkalescens-Dispar group was considered, so that a total of 58 strains $(97 \%$ ) could be identified. Of the I I strains of the Alkalescens-Dispar group, six ( $55 \%$ ) could be identified by the combined $E$. coli/Alkalescens-Dispar group scores. Two strains of $E$. coli, two strains of the Alkalescens-Dispar group and three strains belonging to the group but not typical of either taxon (recorded in the Alkalescens-Dispar group in Table 3) could not be identified by the computer method as identification scores in Shigella reached a level which prevented identification.

Flavobacterium. (Brody, Moore \& King, 1958; King, I959; Cabrera \& Davis, 196I; Sugathadasa \& Arseculeratne, 1963; Nelson \& Shelton, 1965.) Only one species, Flavobacterium meningosepticum, was included and all of the II strains were identified correctly.

Hafnia. (Sakazaki, 196I; Fife et al. 1965; Carpenter, Lapage \& Steel, 1966.) One species, Hafnia alvei, was included. Of the 18 strains of $\mathrm{H}$. alvei, I7 (94\%) were correctly identified and one strain did not identify though the highest score was $H$. alvei.

Klebsiella. (Brooke, I95I $b$; Lautrop, 1956; Cowan, Steel, Shaw \& Duguid, 1960; Fife et al. I965; Slopek \& Durlakowa, 1967; Kaluzewski, 1967.) Difficulty was experienced in the identification of strains of this genus. In Matrix 66 we included the taxa in the classification of Cowan et al. (1960); however, we were unable to identify the majority of the strains. A numerical taxonomy study of 177 strains of the Klebsiella and related groups (Bascomb et al. 1971) was carried out and the taxa used in Matrix 68 were as follows: Klebsiella aerogenes and $K$. oxytoca; K. pneumoniae; K. ozaenae; $K$. rhinoscleromatis; and an unnamed group of Klebsiella whose characteristics were described by Bascomb et al. (197I). Of the 89 strains of the combined $K$. aerogenes and $K$. oxytoca group (which includes $K$. edwardsii and its two varieties), $78(88 \%)$ were identified correctly and a further six $(7 \%)$ were identified if the identification scores for the combined $K$. aerogenes and $K$. oxytoca group were added to those for $K$. pneumoniae. The remaining five strains all had the combined $K$. aerogenes and $K$. oxytoca group as the highest score and as the next highest one of the other Klebsiella groups. All of the six strains of $K$. ozaenae, five strains of $K$. pneumoniae, six strains of $K$. rhinoscleromatis and four strains of the unnamed Klebsiella group were identified correctly.

Kluyvera. (Asai, Okumura \& Tsunoda, 1957; Eddy, 1960; Asai, Iizuka \& Komagata, 1962.) Asai et al. (1962) have suggested that this genus should be included in the genus Escherichia. However, the genus appeared to constitute a separate taxon as the three avail- 
able strains were identified correctly in a taxon for Kluyvera included in the matrix, and the identification scores for Escherichia coli, the Alkalescens-Dispar group, or Citrobacter did not prevent identification.

Moraxella. (Henriksen, 1960, 1963; Bøvre \& Henriksen, 1962; Piéchaud, I963; Bijsterveld, 1967.) Sufficient suitable tests were not included in the matrix to separate the species of the genus Moraxella adequately, therefore a combined taxon of all Moraxella species was included. Of a total of I3 strains of Moraxella, nine $(69 \%)$ were correctly identified into this taxon: two of three strains of $M$. liquefaciens, two of three strains of $M$. bovis, two strains of $M$. nonliquefaciens, two of $M$. lacunata, and one of $M$. osloensis. In addition to the two strains of the above species which did not identify, one strain each of $M$. phenylpyruvica and $M$. kingii did not identify. Identification was only moderately successful in this taxon and was prevented in some cases by the scores for Acinetobacter lwoffi .

Pasteurella. (Stableforth \& Galloway, 1959; Steel \& Midgley, 1962; Smith \& Thal, I965.) Four taxa were included at first - Pasteurella multocida (Jones, 1921; Smith, 1958; Talbot \& Sneath, I960; Watt, I965), P. haemolytica (Newsom \& Cross, 1932; Biberstein, Myer \& Kennedy, 1958; Biberstein, Gills \& Knight, 1960; Smith, 1961; Boháček \& Mráz, 1967), $P$. pneumotropica (Jawetz, I950) and P. ureae (Henriksen \& Jyssum, 1960, 1961; Henriksen, I96r, I962; Omland \& Henriksen, I96r; Jones, I962; Jones \& O'Connor, I962; Heyl, I963; Wang \& Haiby, I966) - and information on two new unnamed species was obtained from Hoag, Wetmore, Rogers \& Meier (1962) and Brodie \& Henderson (1963).

Strains of this group were difficult to identify and identification was more successful when Pasteurella multocida was divided into two biotypes and $P$. haemolytica into biotype and biotype T. Of the I 3 strains of $P$. ureae, I $2(92 \%)$ were identified correctly and one failed to identify. Of the six strains of $P$. pneumotropica, five $(83 \%)$ were identified correctly, confirming the separation of this taxon from $P$. multocida. Atypical strains of $P$. multocida proved difficult to identify though several experimental matrices were tested, finally the typical $P$. multocida strains were included as matrix biotype I and strains (more commonly found from dog bites) which failed to grow on MacConkey's agar, and usually did not produce acid from any sugar other than glucose and sucrose, formed matrix biotype 2 . With these two biotypes in the matrix, 2 I $(84 \%)$ of the 25 strains of $P$. multocida matrix biotype I were identified correctly. The remaining four strains failed to identify and were not identified into a combined P. multocida matrix biotype I/biotype 2 taxon. None of the four strains of matrix biotype 2 were identified into this taxon - however, they did identify into a combined $P$. multocida matrix biotype I/biotype 2 taxon. None the less the taxon was retained as the overall identification of strains of $P$. multocida was more successful than if the biotypes were combined. Of 23 strains of $P$. haemolytica biotype A, seven $(30 \%)$ identi fied correctly and of nine strains of $P$. haemolytica biotype T, five $(56 \%)$ identified correctly while one strain identified in a combined $P$. haemolytica biotype A/biotype T taxon. These identification rates were unsatisfactory, largely due to the number of biopatterns obtained and the large number of strains with two, three, four or five test differences from the matrix entries of 0.99 and 0.01 . A numerical taxonomy study of a large number of Pasteurella strains is needed.

Plesiomonas. (Ewing et al. I96I; Habs \& Schubert, 1962; Eddy \& Carpenter, 1964.) One species was included in this genus, Plesiomonas shigelloides, and all six strains of this homogeneous taxon were correctly identified.

Proteus and Providencia. (Stuart, Wheeler \& McGann, 1946; Singer \& Bar-Chay, I954; Shaw \& Clarke, I955; Ewing, Suassuna \& Suassuna, 1960; Sen, 1962; Richard, I965, 1966; Prakash, Dayal \& Kalra, 1966; Giammanco, 1966; Rauss \& Vörös, 1967.) Six species 
were included: Proteus mirabilis, P. morganii, P. rettgeri, P. vulgaris, Providencia alcalifaciens and Providencia stuartii (corresponding to Providencia biotypes A and B respectively). Little difficulty was experienced in the identification of strains of these genra. All the 40 strains of $P$. mirabilis, 12 of $P$. rettgeri, 9 of $P$. vulgaris, 27 of Providencia alcalifaciens and 3 of Providencia stuartii were identified correctly. Of 19 strains of $P$. morganii, $18(95 \%)$ were identified correctly and the other strain failed to reach identification level due to the identification score for Providencia alcalifaciens.

Pseudomonas. (Rhodes, I959; Hugh \& Ryschenkow, I96I; Park, I962; Hugh \& Leifson, 1963; Colwell, 1964, Wahba \& Darrell, 1965; Redfearn, Palleroni \& Stanier, 1966; Stanier, Palleroni \& Doudoroff, I966; Weaver, 1967; Lapage, Hill \& Reeve, I968.) Pseudomonas aeruginosa, $P$. fluorescens, $P$. mallei, $P$. maltophilia and $P$. pseudomallei were included as separate taxa. Other species of Pseudomonas were not included as the tests in the matrix were not suitable for their differentiation. Of the 39 strains of $P$. aeruginosa, $35(90 \%)$ were correctly identified and the remaining strains failed to identify due to the identification scores reached by $P$. fluorescens. All the eight strains of $P$. fluorescens were correctly identified, and of the nine strains of $P$. mallei, seven $(78 \%)$ were correctly identified and two failed to identify due to the scores reached by Moraxella. Of the 13 strains of $P$. maltophilia, I I $(85 \%)$ were correctly identified and, with the other two strains, identification was prevented in one case by the score for Comamonas and in the other for Acinetobacter Iwoffii. Of the I7 strains of $P$. pseudomallei, I $3(76 \%$ ) were correctly identified and the other four were not, owing to the scores reached by $P$. fluorescens. The tests used in the matrix are not entirely satisfactory for the differentiation of even these Pseudomonas spp.

R. M. Bacterium. (Ross et al. 1966.) This unclassified enterobacterium, isolated from red mouth disease of trout, was included in the matrix since the distribution of the organism was unknown. All three strains of the taxon were identified correctly.

Salmonella. (Hinshaw, Browne \& Taylor, I943; Blaxland, Sojka \& Smither, I956; Kauffmann, 1961, 1965, I966; Costin et al., 1964; Ewing \& Ball, 1966; Ewing \& Fife, 1966.) Included as taxa in the matrix were the four Salmonella subgenera I, II, III (= Arizona) and IV. In addition, $S$. choleraesuis, $S$. gallinarum, S. ferlac, $S$. paratyphi A, S. pullorum and $S$. typhi were included as separate taxa. The two strains of $S$. choleraesuis, all five strains of $S$. gallinarum, the one strain of $S$. ferlac, both strains of $S$. paratyphi A and all seven strains of subgenus IV were correctly identified. Only I of the 5 strains of $S$. pullorum failed to identify due to the score reached by $S$. gallinarum. Of the seven strains of $S$. typhi, six $(86 \%)$ identified correctly, including a lactose-positive strain which was included in the series. The strain which did not identify differed biochemically in four tests from a typical strain of $S$. typhi, but was assumed to be a strain of $S$. typhi, as it had the antigenic structure Rough, Vi:d.

Of the 24 strains of Salmonella subgenus I, $20(83 \%)$ were identified correctly. A strain of Salmonella thompson, a species which belongs to subgenus I, was atypical in several characters and failed to identify. Two other strains of subgenus I, S. sendai and S. typhisuis, also failed to identify. These two species, though classified in Salmonella subgenus I (Kauffmann, I961), have rather different characteristics from those typical of the subgenus. A strain of $S$. abortusovis identified as $S$. choleraesuis - a species also classified in subgenus I but entered as a separate taxon in Matrix 68. Salmonella species are, however, recognized largely on serological rather than biochemical grounds and it would be difficult, if not impractical, to add every aberrant serotype as a different taxon. This identification of the strain of $S$. abortusovis into $S$. choleraesuis is the only instance in the whole series of strains in which a strain of a taxon in the matrix identified in the incorrect taxon; it has been scored 
as not identified in Table 3. Subgenera II and III presented more difficulty as five of ten strains in subgenus II identified in that taxon and a further three were identified in a combined group of subgenera II and III. Similarly, three of the eight strains of subgenus III identified in that taxon and a further four were identified in the combined group. A strain of $S$. basel (a serotype classified in subgenus II) failed to identify in subgenus II or in a combined subgenus II and III as identification was prevented by subgenus I. A strain of $S$. windhoek (which belongs to subgenus II) also failed to identify, though subgenus II reached the highest identification score and subgenus IV the next highest, as might be expected since this strain of $S$. windhoek grew in $\mathrm{KCN}$ medium - a characteristic of subgenus IV. The remaining strain of subgenus III which did not identify in that taxon or in combined subgenera II and III had the highest identification score for subgenus III though identification level was not reached.

There does not appear to be a great distinction between subgenera II and III and it has been suggested that they should be combined. A numerical taxonomy study, based on both biochemical and serological data, of the genus Salmonella is needed to support the validity of the subgenera and to establish which species may form further clusters. Many atypical strains are placed into the subgenera and the value of the subgenera as a primary distinction needs to be established; more than four subgenera may be required, particularly if they are lowered in rank to Salmonella species, relegating the present species to serotypes (Le Minor, Rohde \& Taylor, 1970).

Serratia. (Ewing, Davis \& Reavis, 1959; Martinec \& Kocur, 196r ; Ewing, Davis \& Johnson, 1962; Ewing, Johnson \& Davis, 1962; Fife et al. 1965; Sedlák, Dlabac \& Motlíková, 1965.) Two taxa were included - Serratia matrix biotype 1 , which corresponded to Serratia marcescens, and Serratia matrix biotype 2, which has been described in Bascomb et al. (I97I) and resembles phenon B of Grimont (1969). These strains of Serratia were negative in ornithine decarboxylase, produced acid from arabinose, lactose, raffinose and xylose and were anaerogenic. They differ from the description of $S$. marcescens var. kiliensis (Fife et al. 1965 ) in producing acetoin at $37^{\circ} \mathrm{C}$ and room temperature and by producing acid from arabinose and raffinose. Of the $\mathrm{I} 2$ strains of Serratia matrix biotype I, I I $(92 \%)$ were correctly identified as were the three strains of Serratia matrix biotype 2. The failure of one strain of Serratia matrix biotype I to identify was caused by the score for Enterobacter liquefaciens. It has been suggested that $S$. marcescens and $E$. liquefaciens are closely related (Hamon, Le Minor \& Peron, 1970; Bascomb et al. 1971).

Shigella. (Carpenter et al. 1966; Adler \& King, 1967; Carpenter, 1968.) Great difficulty was experienced in making suitable taxa for use in the matrix in the identification of Shigella species, and a number of experimental matrices were tested, even one which included the biochemical reactions of all the described serotypes of the species Shigella dysenteriae, S. flexneri, S. boydii and S. sonnei. This complete matrix did not prove satisfactory as there were insufficient biochemical differences between the serotypes to enable identification to be reached. Many strains of particular serotypes are biochemically atypical. For identification it was found most satisfactory to use only two taxa, Shigella sonnei and 'Shigella - other serotypes'.

All the seven strains of Shigella sonnei were correctly identified, while only $27(79 \%)$ of the 34 strains of other serotypes could be correctly identified. Of the ten strains of $S$. dysenteriae, nine $(90 \%)$ identified correctly, while the identification score for $S$. sonnei prevented identification of the remaining strain. Of I I strains of $S$. boydii, six $(54.5 \%)$ identified correctly and the identification of the other five was prevented by the score for the Alkalescens-Dispar group. Of 13 strains of S. flexneri, $12(92 \%)$ identified correctly and one 
strain failed to identify due to the score for Salmonella gallinarum. In all these cases the score for 'Shigella - other serotypes' was the highest.

A numerical taxonomy study of a large number of Shigella strains seems to be required to define the biochemical clusters in the genus Shigella. Until such a study has been made it is not certain that Shigella strains other than $S$. sonnei can be clearly separated from Escherichia coli by numerical identification, therefore such a study should include members of $E$. coli and the Alkalescens-Dispar group.

Vibrio. (Pollitzer, 1955; Burrows \& Pollitzer, I958; Davis \& Park, I962; Fujino et al. 1965; Carpenter, I966; Ewing, Davis \& Martin, I966; Sakazaki, Gomez \& Sebald, I967; Baross \& Liston, 1968.) Two taxa were included - Vibrio cholerae together with other related vibrios such as the El Tor biotype and the so-called non-agglutinable (NAG) vibrios - and as a separate taxon $V$. parahaemolyticus. Organisms previously classified as Vibrio, such as $V$. fetus, were considered to belong to the genus Campylobacter (Sebald \& Véron, 1963), but as they grow poorly, if at all, on nutrient agar they were not included in this study. Other marine vibrios apart from $V$. parahaemolyticus were not included. Of the ten strains of $V$. cholerae, nine $(90 \%)$ were correctly identified and failure of identification of the one strain was due to the score reached by $V$. parahaemolyticus. Both strains of $V$. parahaemolyticus were correctly identified.

Yersinia. (Chen, I949; Pollitzer, I954; Daniëls, 1963; Daniëls \& Goudzwaard, I963; Knapp \& Thal, I963; Mollaret, I966, 1967; Winblad, Niléhn \& Jonsson, I966; Niléhn, 1967; Jansson, Wallgren \& Ahvonen, I968.) Three species were included - Yersinia pestis, $Y$. pseudotuberculosis and $Y$. enterocolitica. All seven strains of $Y$. enterocolitica, 12 of $Y$. pestis and 24 of $Y$. pseudotuberculosis were identified correctly.

Strains of taxa not in the matrix. The results obtained with these 5I strains are given in Table 5 and all but II $(2 \mathrm{I} \cdot 6 \%$ ) failed to identify. For those strains which identified, the number of test results differing from the matrix entries of 0.99 or 0.0 I for the taxon into which they identified are shown in Table 5. One of I I strains of Agrobacterium tumefaciens differed from the others in a number of characters and identified as Flavobacterium meningosepticum, which it resembled in all but two characters. Three of four strains of Neisseria catarrhalis and one of $N$. cinerea showed no test differences from the matrix entries of 0.99 or 0.0 I for Moraxella and identified in that taxon. Two strains of Neisseria pharyngis identified as Pasteurella ureae and showed only one and two test result differences from the matrix entries of 0.99 or 0.0 I for that taxon. This shows only that they resemble each other in the tests in the matrix and that the less reactive Parvobacteriaceae may be confused with Neisseria.

Since only a limited number of taxa of Pseudomonas ( $P$. aeruginosa, $P$. fluorescens, $P$. mallei, $P$. maltophilia, and $P$. pseudomallei) were included in the matrix, a number of strains of other species of Pseudomonas (Table 5) were tested. Two of the three strains of P. stutzeri showed no test differences from $P$. fluorescens in the tests in the matrix and identified in that taxon. However, all the strains of Pseudomonas belonging to a species not in the matrix and which failed to identify had as their highest identification score one of the taxa of Pseudomonas present in the matrix. Identification by our method of species of this genus requires further study and a further matrix. One strain of Rhizobium meliloti which showed no test differences with the 0.99 or 0.0 I entries for $P$. fluorescens identified in this species. This is not unexpected as suitable tests for their differentiation were not included.

Since only taxa for Vibrio cholerae and $V$. parahaemolyticus had been included in the matrix, one strain of each of four other Vibrio species were tested (Table 5). One - V. anguillarum - identified as Aeromonas hydrophila. One strain each of Xanthomonas campestris, 
Table 5. Identification of strains of taxa not in the matrix

Taxon

No. of
strains

Strains identified by the computer

Agrobacterium tumefaciens
Neisseria animalis
N. canis
N. catarrhalis
N. caviae
N. cinerea
N. cuniculi
N. denitrificans
N. flavescens
N. pharyngis
Pseudomonas cepacia
$P$. chlororaphis
$P$. diminuta
$P$. ovalis
$P$. putrefaciens
$P$. stutzeri
Rhizobium japonicum
$R$. meliloti
Vibrio albensis
V. anguillarum
V. fischeri
V. metschnikovii
Xanthomonas campestris
$X$. juglandis
$X$. pelargonii
Zoogloea ramigera
$\quad$ Total

$\begin{array}{rr}\text { II } & \text { I } \\ \text { I } & - \\ \text { I } & -3 \\ \text { I } & -1 \\ \text { I } & - \\ \text { I } & - \\ \text { I } & - \\ 2 & \\ 2 & 2 \\ 4 & - \\ \text { I } & - \\ \text { I } & - \\ \text { I } & - \\ 6 & - \\ 3 & 2 \\ \text { I } & - \\ \text { I } & - \\ \text { I } & - \\ \text { I } & 1 \\ \text { I } & - \\ \text { I } & - \\ \text { I } & - \\ \text { I } & - \\ \text { I } & - \\ \text { I } & - \\ 5 \text { I } & \text { I }\end{array}$

* The number of tests in which the strain gave a + ve result and the matrix entry for the taxon to which it identified was 0.01 or the strain gave a - ve result and the matrix entry was 0.99 .

$X$. juglandis and $X$. pelargonii failed to identify, which is of interest in view of the close relationship phenetically of this genus to Pseudomonas. A strain of Zoogloea ramigera - the type strain (Wisconsin strain, ATCC 19623) proposed by Crabtree \& McCoy (I967) - failed to identify.

\section{DISCUSSION}

The rate of success in identification varied between groups of taxa. The fermentative taxa gave the highest overall rate of identification $(90.8 \%)$ and in $54 \%$ of these taxa all the strains were identified. The non-fermentative taxa gave an overall identification rate of only $82 \cdot 1 \%$ and only $29 \%$ of these taxa gave an identification rate of $100 \%$. Of strains belonging to taxa not included in the matrix, $21.6 \%$ were identified to one of the taxa in the matrix. But as these strains showed so few differences with the $0.99,0.01$ entries in the matrix (Table 5), addition of further tests to the matrix suitable for the differentiation of these taxa is required.

It is not clear exactly what factors operate in successful identification. The number of biopatterns given by strains in a taxon showed no correlation with success in identification in that taxon. The number of 0.99 or 0.0 I differences, for a given taxon, from the taxon closest to it in the matrix does, however, play some part, as a successful identification rate cannot be assumed, though it may be obtained, unless two or more $0.99 / 0.0$ I test differences are between the taxa concerned. The difference in identification rates for fermenters and non- 
fermenters can be accounted for by the lack of discriminating tests for non-fermenters; the identification rate for non-fermenters $(8 \mathrm{r} \cdot 6 \%)$ does not differ significantly from those fermenters in taxa with less than two separating tests $(8 \mathrm{I} \cdot 8 \%)$.

The only fully correlated factor indicated was the number of differences of the strain from the matrix entries of 0.99 or 0.01 for that taxon. Otherwise it would seem to us that there is no method a priori in a biological system of determining whether a probabilistic matrix will operate successfully and an empirical trial has to be made.

In some cases a combined score for two taxa is needed to reach identification, e.g. Escherichia coli and the Alkalescens-Dispar group, which are clearly closely related even if separable. The inclusion of tests to separate such groups, e.g. serological, might overload the matrix with tests inapplicable to most taxa. Moreover, for practical purposes, identification in a combined taxon may be sufficient.

It is also obvious from Table 3 that, with the exception of Actinobacillus lignieresi, the Alkalescens-Dispar group, Pasteurella haemolytica A and T, and 'Shigella-other serotypes', a very high rate of identification was achieved. Many of the strains of the other fermentative taxa which did not identify were either true intermediate strains, or ones which varied from the expected test results in their taxon; such differences tend to be deliberately ignored by the bacteriologist when making a decision about the identification of these strains. If the logic of such decisions could be formulated it might be possible to include it in the identification program.

Similarly, formulation of more precise definitions for taxa would enhance identification. It would remove the weighting often used in conventional identification, e.g. fermentative violet pigmented organisms are considered Chromobacterium violaceum, as were the two strains which failed to identify and yet had three and four test differences from the matrix figures in this study.

We wish to thank the directors of all the laboratories who sent us strains and collaborated in the project. Our thanks are also due to the Public Health Laboratory Service for help and support, and to the Department of Health and Social Security for the grant which made the work possible.

\section{REFERENCES}

AdLER, D. L. \& KING, B. M. (1967). Identification difficulties with Shigella dysenteriae serotype r. American Journal of Clinical Pathology 47, 186-189.

Asar, T., Iizuka, H. \& Komagata, K. (1962). The flagellation of genus Kluyvera. Journal of General and Applied Microbiology 8, I87-19I.

Asai, T., OKumura, S. \& TSUNODA, T. (1957). On the classification of the $\alpha$-ketoglutaric acid-accumulating bacteria in aerobic fermentation. Journal of General and Applied Microbiology 3, 13-33.

Bain, N. \& Shewan, J. M. (1968). Identification of Aeromonas, Vibrio and related organisms. In Identification Methods for Microbiologists B, pp. 80-84. Edited by B. M. Gibbs and D. A. Shapton. Society for Applied Bacteriology Technical Series, no. 2. London: Academic Press.

Baross, J. \& Liston, J. (1968). Isolation of Vibrio parahaemolyticus from the Northwest Pacific. Nature, London 217, I263-1264.

Bascomb, S., Lapage, S. P., Willcox, W. R. \& CuRtis, M. A. (I97I). Numerical classification of the tribe Klebsielleae. Journal of General Microbiology 66, 279-295.

Bhat, P., Myers, R. M. \& CARPENTER, K. P. (1967). Edwardsiella tarda in a study of juvenile diarrhoea. Journal of Hygiene 65, 293-298.

Biberstein, E. L., Gills, M. \& KNIGHT, H. (1960). Serological types of Pasteurella haemolytica. Cornell Veterinarian 50, 283-300.

Brberstein, E. L., MEYER, M. E. \& Kennedy, P. C. (1958). Colonial variation of Pasteurella haemolytica isolated from sheep. Journal of Bacteriology 76, 445-452. 
VAN Bissterveld, O. P. (1967). Acute conjunctivitis and Moraxella. American Journal of Ophthalmology $\mathbf{6}_{3}$, $1702-1705$.

Blaxland, J. D., Sojka, W. J. \& Smither, A. M. (1956). A study of Salm. pullorum and Salm. gallinarum strains isolated from field outbreaks of disease. Journal of Comparative Pathology and Therapeutics 66, $270-277$.

BoHÁCEK, J. \& MrÁz, O. (1967). Basengehalt der Desoxyribonukleinsäure bei den Arten Pasteurella haemolytica, Actinobacillus lignieresii und Actinobacillus equuli. Zentralblatt für Bakteriologie, Parasitenkunde, Infektionskrankheiten und Hygiene (Abteilung I, Originale) 202, 468-478.

Bøvre, K. \& Henriksen, S. D. (1962). An approach to transformation studies in Moraxella. Acta pathologica et microbiologica scandinavica 56, 223-228.

Breed, R. S., Murray, E. G. D. \& Smith, N. R. (1957). Bergey's Manual of Determinative Bacteriology, 7 th edn. Baltimore: Williams and Wilkins.

Brisou, J. \& PRÉVot, A. R. (1954). Etudes de systématique bactérienne. X. Révision des espèces réunies dans le genre Achromobacter. Annales de l'Institut Pasteur 86, 722-728.

Brodie, J. \& Henderson, A. (1963). A new Pasteurella species (?) from a wound infection. Journal of Clinical Pathology 16, 367-369.

Brody, A. J., Moore, H. \& KING, E. O. (1958). Meningitis caused by an unclassified Gram-negative bacterium in newborn infants. American Journal of Diseases of Children 96, I-5.

Brooke, M. S. (195I a). The occurrence of B5W (B. anitratum) strains in Denmark. Acta pathologica et microbiologica scandinavica $\mathbf{2 8}, 338-342$.

Brooke, M.S. (I95I $b$ ). Biochemical investigations on certain urinary strains of Enterobacteriaceae. I, B. cloacae. 2, 'Providence'. Acta pathologica et microbiologica scandinavica 29, I-8.

Brooke, M. S. (1953). The differentiation of Aerobacter aerogenes and Aerobacter cloacae. Journal of Bacteriology 66, $72 \mathrm{I}-726$.

Burrows, W. \& Pollitzer, R. (I958). Laboratory diagnosis of cholera. Bulletin of the World Health Organization 18, 275-290.

Cabrera, A. H. \& Davis, G. H. (I96I). Epidemic meningitis of the newborn caused by Flavobacteria. American Journal of Diseases of Children ror, 289-295.

Carpenter, K. P. (I966). Isolation and identification of cholera vibrios. Monthly Bulletin of the Ministry of Health and the Public Health Laboratory Service 25, 58-63.

CARPENTER, K. P. (I 968). Identification of Shigella. Association of Clinical Pathologists, broadsheet 60.

Carpenter, K. P., Lapage, S. P. \& Steel, K. J. (I966). Biochemical identification of Enterobacteriaceae. In Identification Methods for Microbiologists, A, pp. 2 I-33. Edited by B. M. Gibbs and F. A. Skinner. Society for Applied Bacteriology Technical Series, no. I. London: Academic Press.

Catsaras, M. \& Buttiaux, R. (1965). Les Aeromonas dans les matières fécales humaines. Annales de l'Institut Pasteur de Lille 16, 85-88.

Cetin, E. T. (1962). Moraxella glucidolytica type 5. (Acinetobacter anitratum type 5.) Annales de l'Institut Pasteur 102, 756-759.

Chen, T. H. (1949). The behaviour of Pasteurella pestis in glycerin and rhamnose mediums. Journal of Infectious Diseases 85, 97-100.

COLwell, R. R. (I964). A study of features used in the diagnosis of Pseudomonas aeruginosa. Journal of General Microbiology 37, 18 I-I94.

Conn, H. J. (1942). Validity of the genus Alcaligenes. Journal of Bacteriology 44, 353-360.

Costin, I. D., Petrica, L., Garoiu, M., Onică, P., Pelle, A. \& Dinu, N. (I964). Correlation between origin and biochemical behaviour of Salmonella gallinarum and Salmonella pullorum cultures. Zentralblatt für Bakteriologie, Parasitenkunde, Infektionskrankheiten und Hygiene (Abteilung I, Originale) 194, 342350.

Courtieu, A.-L. Chassignol, S. \& Longeray, C. (196I). Caractères bactériologiques de 2 I 4 souches de Moraxella lwoffii et de M. glucidolytica (Acinetobacter). Annales de l'Institut Pasteur 1oo, I I6-I 22.

CowAN, S. T. \& STEEL, K. J. (I965). Manual for the Identification of Medical Bacteria. Cambridge University Press.

Cowan, S. T., Steel, K. J., Shaw, C. \& Duguid, J. P. (1960). A classification of the Klebsiella group. Journal of General Microbiology 23, 60I-6I2.

Crabtree, K. \& MCCoy, E. (1967). Zoogloea ramigera Itzigsohn, identification and description. International Journal of Systematic Bacteriology 17, I-IO.

Crawford, I. P. (1954). A new fermentative pseudomonad, Pseudomonas formicans, n.sp. Journal of Bacteriology $68,734-738$. 
Cruickshank, J. C. (1935). A study of the so-called Bacterium typhiflavum. Journal of Hygiene 35, 354-37I.

DaniëLS, J. J. H. M. (1963). Untersuchungen an als Pasteurella pseudotuberculosis diagnostizierten Stämmen von Chinchillas. Zentralblatt für Veterinärmedizin ro, 413-417.

DaniëLs, J. J. H. M. \& GoudzwaARd, C. (I963). Enkele stammen van een op Pasteurella pseudotuberculosis gelijkend niet geidentificeerd species, geisoleerd bij knaagdieren. Tijdschrift voor Diergeneeskunde 88, $96-102$.

Davis, B. R. \& EwING, W. H. (1966). The Biochemical Reactions of Citrobacter freundii. U.S. National Communicable Disease Center, Atlanta, Georgia.

Davis, G. H. G. \& Park, R. W. A. (1962). A taxonomic study of certain bacteria currently classified as a Vibrio species. Journal of General Microbiology 27, IOI-119.

Dybowski, W. \& Franklin, D. A. (I968). Conditional probability and the identification of bacteria: a pilot study. Journal of General Microbiology 54, 215-229.

EDDY, B. P. (1960). Cephalotrichous, fermentative Gram-negative bacteria: the genus Aeromonas. Journal of Applied Bacteriology 23, $216-249$.

EdDy, B. P. (1962). Further studies on Aeromonas. I. Additional strains and supplementary biochemical tests. Journal of Applied Bacteriology 25, I37-146.

Eddy, B. P. \& CARPENTER, K. P. (1964). Further studies on Aeromonas. II. Taxonomy of Aeromonas and C27 strains. Journal of Applied Bacteriology 27, 96-109.

EDWARDs, P. R. \& EWING, W. H. (1962). Identification of Enterobacteriaceae, 2nd edn. Minneapolis: Burgess Publishing Company.

Ewing, W. H. \& BALl, M. M. (1966). The Biochemical Reactions of the Members of the Genus Salmonella. U.S. National Communicable Disease Center, Atlanta, Georgia.

Ewing, W. H., Davis, B. R. \& Johnson, J. G. (1962). The genus Serratia: its taxonomy and nomenclature. International Bulletin of Bacteriological Nomenclature and Taxonomy 12, 47-52.

EwING, W. H., DAVIS, B. R. \& MARTIN, W. J. (I966). Outline of Methods for the Isolation and Identification of Vibrio cholerae. U.S. National Communicable Disease Center, Atlanta, Georgia.

Ewing, W. H., Davis, B. R. \& Reavis, R. W. (I959). Studies on the Serratia group. U.S. National Communicable Disease Center, Atlanta, Georgia.

EwING, W. H. \& Fife, M. A. (1966). A summary of the biochemical reactions of Arizona arizonae. International Journal of Systematic Bacteriology 16, 427-433.

EwING, W. H., Hugh, R. \& Johnson, J. G. (1961). Studies on the Aeromonas Group. U.S. National Communicable Disease Center, Atlanta, Georgia.

Ewing, W. H., Johnson, J. G. \& Davis, B. R. (1962). The Occurrence of Serratia marcescens in Nosocomial Infections. U.S. National Communicable Disease Center, Atlanta, Georgia.

Ewing, W. H., McWhorter, A. C., Ball, M. M. \& Bartes, S. F. (1967). The Biochemical Reactions of Edwardsiella tarda, a new Genus of Enterobacteriaceae. U.S. National Communicable Disease Center, Atlanta, Georgia.

Ewing, W. H., McWhorter, A. C., Escobar, M. R. \& Lubin, A. H. (I965). Edwardsiella, a new genus of Enterobacteriaceae based on a new species, E. tarda. International Bulletin of Bacteriological Nomenclature and Taxonomy 15, 33-38.

Ewing, W. H., Suassuna, I. \& Suassuna, I. R. (1960). The Biochemical Reactions of Members of the Genus Proteus. U.S. National Communicable Disease Center, Atlanta, Georgia.

Fife, M. A., Ewing, W. H. \& Davis, B. R. (1965). The Biochemical Reactions of the Tribe Klebsielleae. U.S. National Communicable Disease Center, Atlanta, Georgia.

Frederiksen, W. (1970). Citrobacter koseri (n.sp.) a new species within the genus Citrobacter, with a comment on the taxonomic position of Citrobacter intermedium (Werkman and Gillen). Publications de la Faculté des Sciences de l'Université J. E. Purkyne, Brno K 47, 89-94.

Fujno, T., Minatani, T., Yasuda, J., Kondo, M., Takeda, Y., Akita, Y., Kotera, K., OKada, M., Nishimune, H., Shimizu, Y., Tamura, T. \& Tamura, Y. (1965). Taxonomic studies on the bacterial strains isolated from cases of 'Shirasu' food-poisoning (Pasteurella parahaemolytica) and related microorganisms. Biken Journal 8, 63-7I.

Galarneault, T. P. \& Leifson, E. (1956). Taxonomy of Lophomonas n.gen. Canadian Journal of Microbiology 2, 102-110.

Giammanco, G. (1966). La $\beta$-D-galactosidase dans le groupe Proteus-Providencia. Annales de l'Institut Pasteur 110, I20-125. 
Gillard, G. L. (1967). Achromobacter and Moraxella (tribe Mimeae): a review and new studies. American Journal of Medical Technology 33, 201-220.

GraHAM, D. C. \& HodGKISs, W. (I967). Identity of Gram-negative, yellow pigmented, fermentative bacteria isolated from plants and animals. Journal of Applied Bacteriology 30, I 75-189.

Griffin, P. J., Snieszko, S. F. \& Friddle, S. B. (1953). A more comprehensive description of Bacterium salmonicida. Transactions of the American Fisheries Society 82, 129-138.

Grimes, M. (196r). Classification of the Klebsiella-Aerobacter group with special reference to the cold-tolerant mesophilic Aerobacter types. International Bulletin of Bacteriological Nomenclature and Taxonomy II, I I I-I 29.

Grimont, A. D. (1969). Les Serratia: étude taxometrique. M.D. Thesis, University of Bordeaux.

Habs, H. \& Schubert, R. H. W. (I962). Über die biochemischen Merkmale und die taxonomische Stellung von Pseudomonas shigelloides (Bader). Zentralblatt für Bakteriologie, Parasitenkunde, Infektionskrankheiten und Hygiene (Abteilung I, Originale) 186, 316-327.

Hamon, Y., Le Minor, L. \& Peron, Y. (1970). Les bactériocines d'Enterobacter liquefaciens. Intéret taxonomique de leur étude. Comptes rendus hebdomadaire des séances de l'Académie des sciences, Paris $\mathrm{D} 270$, $886-889$.

Hendrie, M. S., Hodgkiss, W. \& Shewan, J. M. (i964). Considerations on organisms of the Achromobacter-Alcaligenes group. Annales de l'Institut Pasteur de Lille 15, 43-59.

HeNRIKSEN, S. D. (I960). Moraxella. Some problems of taxonomy and nomenclature. International Bulletin of Bacteriological Nomenclature and Taxonomy ro, 23-28.

Henriksen, S. D. (1961). Pasteurella haemolytica var. ureae. Acta pathologica et microbiologica scandinavica 53, 425-429.

Henriksen, S. D. (I962). Some Pasteurella strains from the human respiratory tract. Acta pathologica et microbiologica scandinavica $\mathbf{5 5}, 355-356$.

Henriksen, S. D. (1963). Mimeae. The standing in nomenclature of the names of this tribus and of its genera and species. International Bulletin of Bacteriological Nomenclature and Taxonomy 13, 5 I-57.

Henriksen, S. D. \& Jyssum, K. (1960). A new variety of Pasteurella haemolytica from the human respiratory tract. Acta pathologica et microbiologica scandinavica 50, 443 .

Henriksen, S. D. \& JySSUM, K. (1961). A study of some Pasteurella strains from the human respiratory tract. Acta pathologica et microbiologica scandinavica 5I, 354-368.

Heyl, J. G (1963). A study of Pasteurella strains from animal sources. Antonie van Leeuwenhoek 29, 79-83.

Hinshaw, W. R., Browne, A. S. \& TAYlor, T. J. (1943). Fermentation of maltose by Salmonella pullorum. Journal of Infectious Diseases 72, 197-201.

Hoag, W. G, Wetmore, P. W., Rogers, J. \& Meier, H. (i962). A study of latent Pasteurella infection in a mouse colony. Journal of Infectious Diseases $111,135-140$.

Hugh, R. \& LeIFSON, E. (1953). The taxonomic significance of fermentative versus oxidative metabolism of carbohydrates by various Gram negative bacteria. Journal of Bacteriology 66, 24-26.

Hugh, R. \& LeIfSON, E. (I963). A description of the type strain of Pseudomonas maltophilia. International Bulletin of Bacteriological Nomenclature and Taxonomy 13, 133-138.

Hugh, R. \& Ryschenkow, E. (1961). Pseudomonas maltophilia, an alcaligenes-like species. Journal of General Microbiology 26, $123-132$.

Jansson, E., Wallgren, G. R. \& Ahvonen, P. (1968). Yersinia enterocolitica as a cause of acute mesenteric lymphadenitis. Acta paediatrica scandinavica 57, 448-450.

JAWETZ, E. (1950). A pneumotropic Pasteurella of laboratory animals. I. Bacteriological and serological characteristics of the organism. Journal of Infectious Diseases 86, I 72-183.

Jøker, R. N., Nørholm, T. \& Siboni, K. (I965). A case of neonatal meningitis caused by a yellow enterobacter. Danish Medical Bulletin I2, I28-130.

Jones, F. S. (I92I). A study of Bacillus bovisepticus. Journal of Experimental Medicine 34, 56I-577.

JoNES, D. M. (I962). A pasteurella-like organism from the human respiratory tract. Journal of Pathology and Bacteriology 83, 143-15I.

Jones, D. M. \& O'Connor, P. M. (1962). Pasteurella haemolytica var. ureae from human sputum. Journal of Clinical Pathology r5, 247-248.

KaluzewsKr, S. (1967). Taxonomic position of indole positive strains of Klebsiella. Experimental Medicine and Microbiology (formerly Medycyna Doświadczalna i Mikrobiologia) 19, 350-359.

Kauffmann, F. (196I). Die Bakteriologie der Salmonella-species. Copenhagen: Munksgaard.

Kauffmann, F. (1965). Die Diagnose von Arizona-Kulturen nach dem originalen Kauffmann-WhiteSchema. Pathologia et Microbiologia 28, 575-580. 
Kauffmann, F. (1966). The Bacteriology of Enterobacteriaceae, pp. 57-59. Copenhagen: Munksgaard.

KING, E. O. (1959). Studies on a group of previously unclassified bacteria associated with meningitis in infants. American Journal of Clinical Pathology 31, 24I-247.

Klinge, K. (I959). Zur Systematik von Bacterium anitratum, Diplococcus mucosus und Moraxella lwoffii. Archiv für Hygiene und Bakteriologie 143, 587-606.

KNAPP, W. \& THAL, E. (1963). Untersuchungen über die kulturellbiochemischen, serologischen, tierexperimentellen und immunologischen Eigenschaften einer vorläufig 'Pasteurella X' benannten Bakterienart. Zentralblatt für Bakteriologie, Parasitenkunde, Infektionskrankheiten und Hygiene (Abteilung I, Originale) I90, $472-484$.

KoOnTZ, F. P. \& FABer, J. E. (1963). A taxonomic study of some Gram-negative, non-fermenting bacteria. Canadian Journal of Microbiology 9, 499-507.

LAPAGE, S. P. \& BASCOMB, S. (1968). Use of selenite reduction in bacterial classification. Journal of Applied Bacteriology 3r, 568-580.

Lapage, S. P., Bascomb, S., Willcox, W. R. \& Curtis, M. A. (i970). Computer identification of bacteria. In Automation, Mechanization and Data Handling in Microbiology, pp. I-22. Edited by A. Baillie and R. J. Gilbert. Society for Applied Bacteriology Technical Series, no. 4. London: Academic Press.

Lapage, S. P., Bascomb, S., Willcox, W. R. \& Curtis, M. A. (1973). Identification of bacteria by computer: general aspects and perspectives. Journal of General Microbiology 77, 273-290.

Lapage, S. P., Hill, L. R., \& Reeve, J. D. (1968). Pseudomonas stutzeri in pathological material. Journal of Medical Microbiology r, I95-202.

LAUTROP, H. (1956). Gelatin-liquefying Klebsiella strains (Bacterium oxytocum (Flügge)). Acta pathologica et microbiologica scandinavica 39, 375-384.

LaUtrop, H. (1960). Laboratory diagnosis of whooping-cough or Bordetella infections. Bulletin of the World Health Organization 23, I 5-35.

LeCLerc, H. (1962). Étude biochimique d'Enterobacteriaceae pigmentées. Annales de l'Institut Pasteur 102, 726-741.

Le Minor, L., Rohde, R. \& TAylor, J. (1970). Nomenclature des Salmonella. Annales de l'Institut Pasteur II9, 206-210.

Macierewicz, M. (1966). A proposal of a new group (genus) of Enterobacteriaceae. Medycyna Doświadczalna i Mikrobiologia 18, 337-343.

Mannheim, W. \& STENZel, W. (1962). Zur Systematik der obligat aeroben gramnegativen Diplobakterien des Menschen. Zentralblatt für Bakteriologie, Parasitenkunde, Infektionskrankheiten und Hygiene (Abteilung I, Originale) r86, 55-83.

MARTINeC, T. \& KocUR, M. (I96I). Contribution to the taxonomic studies of Serratia kiliensis (Lehmann et Neumann) Bergey. International Bulletin of Bacteriological Nomenclature and Taxonomy Ir, 87-90.

Moffett, M. L. \& Colwell, R. R. (I968). Adansonian analysis of the Rhizobiaceae. Journal of General Microbiology 5I, 245-266.

Mollaret, H. H. (1966). L'infection humaine a 'Yersinia enterocolitica' Pathologie et Biologie 14, 98I-990.

MollareT, H. H. (1967). L'infection a bacille de Malassez et Vignal (pseudotuberculosis). BD/PL/67.5 WHO Zoon/67.99 (WHO Working Document).

MoORE, H. B. \& PICKETT, M. J. (1960). Organisms resembling Alcaligenes faecalis. Canadian Journal of Microbiology 6, 43-52.

Muraschi, T. F., Friend, M. \& Bolles, D. (1965). Erwinia-like microorganisms isolated from animal and human hosts. Applied Microbiology 13, I28-I 31 .

Nelson, J. D. \& Shelton, S. (1965). Cultural, biochemical, and immunological properties of Mima, Herellea, and Flavobacterium species. Applied Microbiology 13, 80I-807.

Newsom, I. E. \& Cross, F. (1932). Some bipolar organisms found in pneumonia in sheep. Journal of the American Veterinary Medical Association 80, 7 I I-719.

NiLÉHN, B. (1967). Studies on Yersinia enterocolitica. Characterization of 28 strains from human and animal sources. Acta pathologica et microbiologica scandinavica 69, 83-9I.

Nyberg, C. (1935). Bacillus faecalis alcaligenes Petruschky. Zentralblatt für Bakteriologie, Parasitenkunde Infektionskrankheiten und Hygiene (Abteilung I, Originale) r33, 443-449.

OMLAND, T. \& HenRIKSEN, S. D. (I96I). Two new strains of Pasteurella haemolytica var. ureae isolated from the respiratory tract. Acta pathologica et microbiologica scandinavica 53, I I 7-I 20.

PARK, R. W. A. (1962). A study of certain heterotrophic polarly flagellate water bacteria: Aeromonas, Pseudomonas, and Comamonas. Journal of General Microbiology 27, $121-133$. 
PhilliPs, J. E. (1960). The characterisation of Actinobacillus lignieresi. Journal of Pathology and Bacteriology $79,33 I-336$.

Phillips, J. E. (1961). The commensal role of Actinobacillus lignieresi. Journal of Pathology ad Bacteriology 82, 205-208.

PiÉChaud, M. (1963). Mobilité chez les Moraxella. Annales de l'Institut Pasteur 104, 29I-297.

PINTÉR, M. \& BENDE, I. (I968). Biochemical similarity of Acinetobacter lwoffii and Acinetobacter anitratus. Pathologia et microbiologia 3r, 4I-50.

Prvnick, H. \& Sabina, L. R. (1957). Studies of Aeromonas formicans Crawford comb.nov, from soluble oil emulsions. Journal of Bacteriology 73, 247-25I.

Pollitzer, R. (1954). Plague. World Health Organization Monograph no. 22.

Pollitzer, R. (1955). Cholera Studies. 3. Bacteriology. Bulletin of the World Health Organization 12, $777-875$.

Prakash, O., Dayal, S \& Kalra, S. L. (I966). Bacterial aetiology of infantile diarrhoea in a village population with observations on some Providence strains isolated from diarrhoea and non-diarrhoea cases. Indian Journal of Medical Research 54, 705-713.

Prévot, A. R. (1961). Traité de systématique bactérienne. Paris: Dunod.

RAuss, K. \& Vörös, S. (1967). Five new serotypes of Morganella morganii. Acta microbiologica Academiae scientiarum hungaricae 14, 195-198.

Redfearn, M. S., Palleroni, N. J. \& Stanier, R. Y. (1966). A comparative study of Pseudomonas pseudomallei and Bacillus mallei. Journal of General Microbiology 43, 293-3I3.

REPORT of the Enterobacteriaceae Subcommittee of the Nomenclature Committee of the International Association of Microbiological Societies (1958). International Bulletin of Bacteriological Nomenclature and Taxonomy 8, 25-70.

REPORT of the Subcommittee on Taxonomy of the Enterobacteriaceae (1963). International Bulletin of Bacteriological Nomenclature and Taxonomy $\mathbf{1 3}, 69-93$.

Rhodes, M. E. (1959). The characterization of Pseudomonas fuorescens. Journal of General Microbiology 2I, $221-263$.

Richard, C. (1965). Mesure de l'activité uréasique des Proteus au moyen de la réaction phénol-hypochlorite de Berthelot. Annales de l'Institut Pasteur 109, 516-524.

Richard, C. (I966). Caractères biochimiques des biotypes de Providencia; leurs rapports avec le genre Rettgerella. Annales de l'Institut Pasteur I10, I05-114.

RichteR, G. W. \& KRESS, Y. (1967). Observations on commensal cultures of Bordetella bronchiseptica and rat hepatoma cells. Laboratory Investigation I6, I 87-210.

Ristic, M., Herzberg, M., Sanders, D. A. \& Williams, J. W. (1956). Actinobacillosis. I. An evaluation of cultural characteristics of selected strains of Actinobacillus lignieresi. American Journal of Veterinary Research $17,555-562$.

Ross, A. J., Rucker, R. R. \& EWING, W. H. (I966). Description of a bacterium associated with redmouth disease of rainbow trout (Salmo gairdneri). Canadian Journal of Microbiology 12, 763-770.

SAKAZAKI, R. (196I). Studies on the Hafnia group of Enterobacteriaceae. Japanese Journal of Medical Science and Biology 14, 223-24I.

SAKAZAKI, R. (1967). Studies on the Asakusa group of Enterobacteriaceae (Edwardsiella tarda). Japanese Journal of Medical Science and Biology 20, 205-21 2.

Sakazaki, R., GomeZ, C. Z. \& Sebald, M. (1967). Taxonomical studies of the so-called NAG vibrios. Japanese Journal of Medical Science and Biology 20, 265-280.

SCHUBERT, R. H.W. (1960). Untersuchungen über die Merkmale der Gattung Aeromonas. Zentralblatt für Bakteriologie, Parasitenkunde, Infektionskrankheiten und Hygiene (Abteilung I, Originale) 18o, 3I0-327.

SCHUBERT, R. H. W. (196I). Über die biochemischen Merkmale von Aeromonas salmonicida. Zentralblatt für Bakteriologie, Parasitenkunde, Infektionskrankheiten und Hygiene (Abteilung I, Originale) 183, 485-494.

SChUberT, R. H. W. (1962). Über die biochemischen Eigenschaften der anaerogenen Aeromonaden. Zentralblatt für Bakteriologie, Parasitenkunde, Infektionskrankheiten und Hygiene (Abteilung I, Originale) 185, 503-5II.

SCHUBERT, R. H. W. (1963). Über die biochemischen Eigenschaften von Aeromonas hydrophila. Zentralblatt für Bakteriologie, Parasitenkunde, Infektionskrankheiten und Hygiene (Abteilung I, Originale) 188, 62-69.

SCH UBERT, R. H. W. (1964). Zur Taxononie der anaerogen Aeromonaden. Zentralblatt für Bakteriologie, Parasitenkunde, Infektionskrankheiten und Hygiene (Abteilung I, Originale) 193, 343-352. 
SCHUBERT, R. H. W. (1967). The taxonomy and nomenclature of the genus Aeromonas Kluyver and van Niel 1936. International Journal of Systematic Bacteriology 17, 273-279.

Sebald, M. \& VÉRon, M. (1963). Teneur en bases de l'ADN et classification des vibrions. Annales de l'Institut Pasteur 105, 897-910.

Sedlák, J., Dlabac, V. \& Motlíková, M. (1965). The taxonomy of the Serratia genus. Journal of Hygiene, Epidemiology, Microbiology and Immunology 9, 45-53.

SEN, R. (1962). Isolation of strains of the Providence group from cases with diarrhoea in Ibadan, Nigeria, West Africa. Indian Journal of Medical Research 50, 622-626.

Shaw, C. \& Clarke, P. H. (1955). Biochemical classification of Proteus and Providence cultures. Journal of General Microbiology 13, 155-I6I.

Singer, J. \& BAR-Chay, J. (I954). Biochemical investigation of Providence strains and their relationship to the Proteus group. Journal of Hygiene 52, $\mathrm{I}-8$.

Slopek, S. \& Durlakowa, I. (1967). Studies on the taxonomy of Klebsiella bacilli. Archivum Immunologiae et Therapiae Experimentalis $\mathbf{5}, 48 \mathrm{I}-487$.

Sмith, J. E. (1958). Studies on Pasteurella septica. II. Some cultural and biochemical properties of strains from different host species. Journal of Comparative Pathology and Therapeutics 68, 31 5-323.

SMITH, G. R. (196r). The characteristics of two types of Pasteurella haemolytica associated with different pathological conditions in sheep. Journal of Pathology and Bacteriology 81, 43 I-440.

Smith, J. E. \& Thal, E. (1965). A taxonomic study of the genus Pasteurella using a numerical technique. Acta pathologica et microbiologica scandinavica 64, $213-223$.

SNeATH, P. H. A. (1956). Cultural and biochemical characteristics of the genus Chromobacterium. Journal of General Microbiology 15, 70-98.

Stableforth, A. W. \& Galloway, I. A. (1959). Infectious Diseases of Animals. Diseases Due to Bacteria. London: Butterworth.

Stanier, R. Y., Palleroni, N. J. \& Doudoroff, M. (1966). The aerobic pseudomonads: a taxonomic study. Journal of General Microbiology 43, I 59-27I.

SteEL, K. J. \& CowAN, S. T. (I964). Le rattachement de Bacterium anitratum, Moraxella lwoffii, Bacillus mallei et Haemophilus parapertussis au genre Acinetobacter Brisou et Prévot. Annales de l'Institut Pasteur I06, 479-483.

STEEL, K. J. \& MidGLeY, J. (I962). Decarboxylase and other reactions of some Gram-negative rods. Journal of General Microbiology 29, I7I-I 78.

Stuart, C. A., Wheeler, K. M. \& MCGANN V. (1946). Further studies on one anaerogenic paracolon organism, type 2991 I. Journal of Bacteriology 52, 43I-438.

Stuart, C. A., Wheeler, K. M., Rustigian, R. \& Zimmermann, A. (1943). Biochemical and antigenic relationships of the paracolon bacteria. Journal of Bacteriology 45, IOI-I I 9.

Sugathadasa A. A. \& Arseculeratne, S. N. (1963). Neonatal meningitis caused by new serotype of Flavobacterium meningosepticum. British Medical Journal r, 37-38.

Tаlвot, J. M. \& SNeath, P. H. A. (1960). A taxonomic study of Pasteurella septica, especially of strains isolated from human sources. Journal of General Microbiology 22, 303-3 I I.

TAYlor, A. W. (1944). Actinobacillosis in sheep. Journal of Comparative Pathology and Therapeutics 54, 228-237.

Thomas, S. B. \& Elson, K. (I957). Pigmented strains of coli-aerogenes bacteria. Journal of Applied Bacteriology 20, 50-52.

ThORNLEY, M. J. (1967). A taxonomic study of Acinetobacter and related genera. Journal of General Microbiology 49, 2 I I-257.

TunNiclif, E. A. (I94I). A study of Actinobacillus lignieresi from sheep affected with actinobacillosis. Journal of Infectious Diseases $69,52-58$.

UlRich, J. A. \& NeEdham, G. M. (1953). Differentiation of Alcaligenes faecalis from Brucella bronchisepticus by biochemical and nutritional methods. Journal of Bacteriology 65, 210-2 15.

Vallée, A., Thibault, P. \& Second, L, (1963). Contribution a l'étude d'A. lignieresii et d'A. equuli. Annales de l'Institut Pasteur I04, I08-I I4.

Wahba, A. H. \& Darrell, J. H. (1965). The identification of atypical strains of Pseudomonas aeruginosa. Journal of General Microbiology 38, 329-342.

WANG, W. L. L. \& HAIBY, G. (I966). Meningitis caused by Pasteurella ureae. American Journal of Clinical Pathology 45, 562-565.

WatT, D. (1965). Ten Pasteurella strains isolated from human infections. Medical Technology in Australia 7, $172-183$. 
WeAver, R. E. (1967). Laboratory identification of Pseudomonas pseudomallei. Public Health Laboratory 25, 202-204.

Werkman, C. H. \& Gillen, G. F. (1932). Bacteria producing trimethylene glycol. Journal of Bacteriology 23, I67-I82.

WillcoX, W. R., LAPAge, S. P., BAsComb, S. \& CuRTis, M. A. (I973). Identification of bacteria by computer: theory and programming. Journal of General Microbiology 77, 317-330.

WiLson, G. S. \& Miles, A. A. (1964). Topley and Wilson's Principles of Bacteriology and Immunity, 5th edn. London: Edward Arnold.

Winblad, S., NiléHN, B. \& Jonsson, M. (1966). Two further cases, bacteriologically verified, of human infection with 'Pasteurella $X$ ' (Syn. Yersinia enterocolitica). Acta pathologica et microbiologica scandinavica $67,537-541$.

Young, V. M., Kenton, D. M., Hobbs, B. J. \& Moody, M. R. (1971). Levinea, a new genus of the family Enterobacteriaceae. International Journal of Systematic Bacteriology 2I, 58-63. 